medRxiv preprint doi: https://doi.org/10.1101/2021.02.23.21252283; this version posted March 1, 2021. The copyright holder for this preprint

\title{
INTEGRATED TRANSCRIPTOMIC AND NEUROIMAGING BRAIN MODEL DECODES BIOLOGICAL MECHANISMS IN AGING AND ALZHEIMER'S DISEASE
}

Quadri Adewale ${ }^{1,2,3}$, Ahmed F Khan ${ }^{1,2,3}$, Felix Carbonell ${ }^{4}$, Yasser Iturria-Medina ${ }^{1,2,3 *}$, for the Alzheimer's Disease Neuroimaging Initiative ${ }^{5}$.

1 Neurology and Neurosurgery Department, Montreal Neurological Institute, McGill Univ., Montreal, Canada

${ }^{2}$ McConnell Brain Imaging Centre, Montreal Neurological Institute, McGill Univ., Montreal, Canada

${ }^{3}$ Ludmer Centre for Neuroinformatics and Mental Health, McGill Univ., Montreal, Canada

${ }^{4}$ Biospective Inc., Montreal, Canada

${ }^{5}$ Data used in preparation of this article were partly obtained from the Alzheimer's Disease Neuroimaging Initiative (ADNI) database (adni.loni.usc.edu). As such, the investigators within the ADNI contributed to the design and implementation of $A D N I$ and/or provided data but did not participate in analysis or writing of this report. A complete listing of ADNI investigators can be found at:

http://adni.loni.usc.edu/wpcontent/uploads/how to apply/ADNI Acknowledgement List.pdf

* Correspondence to: Y I-M, 3801 University Street, room NW312, Montreal Neurological Institute, McGill University, Montreal, Canada H3A 2B4. Email: iturria.medina@gmail.com

\section{Summary}

Both healthy aging and Alzheimer's disease (AD) are characterized by concurrent alterations in several biological factors. However, generative brain models of aging and $A D$ are limited in incorporating the measures of these biological factors at different spatial resolutions. Here, we propose a personalized bottom-up spatiotemporal brain model which accounts for the direct interplay between hundreds of RNA transcripts and multiple macroscopic neuroimaging modalities (PET, MRI). In normal elderly and AD participants, the model identifies top genes modulating tau and amyloid- $\beta$ burdens, vascular flow, glucose metabolism, functional activity, and atrophy to drive cognitive decline. The results also revealed that $A D$ and healthy aging share specific biological mechanisms, even though $A D$ is a separate entity with considerably more altered pathways. Overall, this personalized model offers novel insights into the multiscale alterations in the elderly brain, with important implications for identifying effective

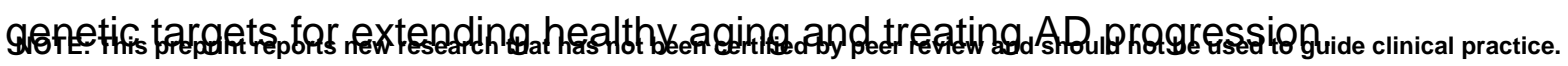


medRxiv preprint doi: https://doi.org/10.1101/2021.02.23.21252283; this version posted March 1, 2021. The copyright holder for this preprint (which was not certified by peer review) is the author/funder, who has granted medRxiv a license to display the preprint in perpetuity.

\section{Highlights}

- A multiscale model integrating gene expression and neuroimaging identifies causal genes driving healthy aging and Alzheimer's disease progression.

- The specific neuroimaging modalities modulated by the causal genes are revealed.

- Healthy aging and Alzheimer's disease share specific biological pathways even though Alzheimer's disease has more altered pathways.

\section{Introduction}

Innovations in healthcare and drug delivery have led to increase in human life expectancy. However, increased lifespan is accompanied by more predisposition to frailty and late-onset Alzheimer's disease (AD) (Guerreiro et al., 2015; Singh et al., 2019). Both healthy aging and $A D$ are complex multifactorial processes, and understanding their molecular mechanisms is crucial for extending longevity and improving quality of life (Alkadhi et al., 2011; Kowald et al., 1996). Indeed, at the microscopic scale $\left(\sim 10^{-6} \mathrm{~m}\right)$, transcriptomics and proteomics analysis of the brain have paved the way for deciphering the mechanistic underpinnings of healthy aging and $A D$ (Dillman et al., 2017; Y. Iturria-Medina et al., 2020; E. C. B. Johnson et al., 2020; Mostafavi et al., 2018; Tanaka et al., 2018). In parallel, macroscopic $\left(\sim 10^{-2} \mathrm{~m}\right)$ imaging phenotypes from PET and MRI are facilitating the detailed characterization of brain changes, such as amyloid- $\beta(A \beta)$ and tau accumulation, glucose hypometabolism, altered cerebrovascular flow and atrophy (Dukart et al., 2013; Jack et al., 2018; Rodrigue et al., 2012; N. Zhang et al., 2017). However, in both aging and disease research, most studies incorporate brain measurements at either micro (e.g. transcriptomics) or macroscopic scale (e.g. PET imaging), failing to detect the direct causal relationships between several biologically factors at multiple spatial resolutions.

Although $A D$ is characterized by the accumulation of amyloid plaques and neurofibrillary tangles, many other biological aberrations have been associated with the disease (neuroinflammation, vascular abnormalities, white matter hyperintensities), leading to changes in diagnostic criteria in recent times (DeTure et al., 2019). The complexity of $A D$ is further compounded by the interplay between these multiple biological factors. A growing body of evidence points to the synergistic interaction 
medRxiv preprint doi: https://doi.org/10.1101/2021.02.23.21252283; this version posted March 1, 2021. The copyright holder for this preprint (which was not certified by peer review) is the author/funder, who has granted medRxiv a license to display the preprint in perpetuity.

between $A \beta$ and tau in driving neuronal loss, functional dysregulation and glucose hypometabolism in AD (laccarino et al., 2017; Ittner et al., 2011; Pascoal et al., 2017; Pickett et al., 2019) . Also, cerebral blood flow (CBF) promotes $A \beta$ clearance, suggesting that vascular dysregulation could impact neuronal function and facilitate $A \beta$ deposition (Qosa et al., 2014; Zlokovic, 2011). To account for the synergy between multiple biological factors, we previously introduced a multifactorial causal model (MCM) (Iturria-Medina et al., 2017), which uses multimodal imaging data to characterize the macroscale intra-regional interactions among any pair of biological factors (tau, $A \beta, C B F$ ) while accounting for the inter-regional spreading of the pathological alterations across axonal and/or vascular connections. However, this multifactorial model did not consider the microscopic properties of the modelled brain regions.

In an initial attempt to integrate brain variables at multiple scales, a few recent studies have used the regional expression patterns of pre-selected genes as complementary information in intra-brain disease spreading models (Freeze et al., 2018; Freeze et al., 2019; Zheng et al., 2019). Applied to Parkinson's disease (PD), improvements in the capacity to explain the regional brain atrophy patterns were observed, based on each brain region's genetic predisposition to the disease. However, most of these studies have selected very specific genes already known for their crucial role in disease (e.g. SNCA, TMEM175, GBA), while disregarding the individual and combined roles of several other relevant gene candidates. Moreover, the analyses have focused on the influence of transcriptomics on a single biological factor at a time, without accounting for the multiplicity of biological alterations and interactions that occur at different spatial scales. As a result, we continue to lack brain generative models integrating a large set of genetic activities with multimodal brain properties.

An integrated multiscale and multifactorial brain model (from genes to neuroimaging and cognition) may be critical to further our understanding of both healthy aging and neurodegeneration, and engender the development of inclusive biomarkers for personalized diagnosis and treatment. Driven by this motivation, here we combine whole-brain transcriptomics, PET and MRI in a comprehensive generative and personalized formulation which we successfully validated in healthy aging and $A D$ progression. This novel approach concurrently accounts for the direct influence of hundreds of genes on regional macroscopic multifactorial effects, the pathological 
medRxiv preprint doi: https://doi.org/10.1101/2021.02.23.21252283; this version posted March 1, 2021. The copyright holder for this preprint (which was not certified by peer review) is the author/funder, who has granted medRxiv a license to display the preprint in perpetuity.

It is made available under a CC-BY-NC-ND 4.0 International license .

spreading of the ensuing aberrations across axonal and vascular networks, and the resultant effects of these alterations on cognition. The proposed framework constitutes a promising technique for the development of effective genetic targets for preventing aging-related disorders and ameliorating existing neurodegenerative conditions.

\section{Results}

\section{Capturing Gene and Macroscopic Factor Interactions in the Human Brain}

Genes control many biological functions, and their dysregulation can cause abnormal development, accelerated aging or disease (Kuintzle et al., 2017; Lee et al., 2013). Aiming to characterize the direct influence of genes on multiple brain processes, here we have developed a multiscale and multifactorial spatiotemporal brain model (Figs. $1 \mathrm{~A}-\mathrm{C}$ ) linking whole-brain gene expression with multiple macroscopic factors typically quantified via molecular PET and MRI modalities (i.e. $A \beta$ and tau proteins, CBF, glucose metabolism, neuronal activity, and grey matter density). This novel approach, called Gene Expression Multifactorial Causal Model (GE-MCM; see Methods), allows quantifying the gene-specific impacts on the longitudinal changes associated with each local macroscopic factor considered, and the gene mediation effects on the pairwise factor interactions (e.g. negative tau effects on neuronal activity) while accounting for the simultaneous spreading of the aberrant effects across physical brain networks (e.g. tau and $A \beta$ region-region propagation via anatomical and vascular connectomes). By using standardized GE maps (Hawrylycz et al., 2012), longitudinal multimodal imaging data and a robust optimization algorithm, the GE-MCM identifies individual transcriptomic-imaging parameters controlling the dynamic changes observed in the macroscopic biological factors considered (Figs. 1A-C). These personalized parameters are assumed to be the gene-specific deviations required for model fitting and thus they quantitatively measure individual gene dysregulation patterns. We hypothesized that the post-hoc analysis of these transcriptomic-imaging parameters will reveal essential pathogenetic mechanisms in health and disease. 
A

B

C

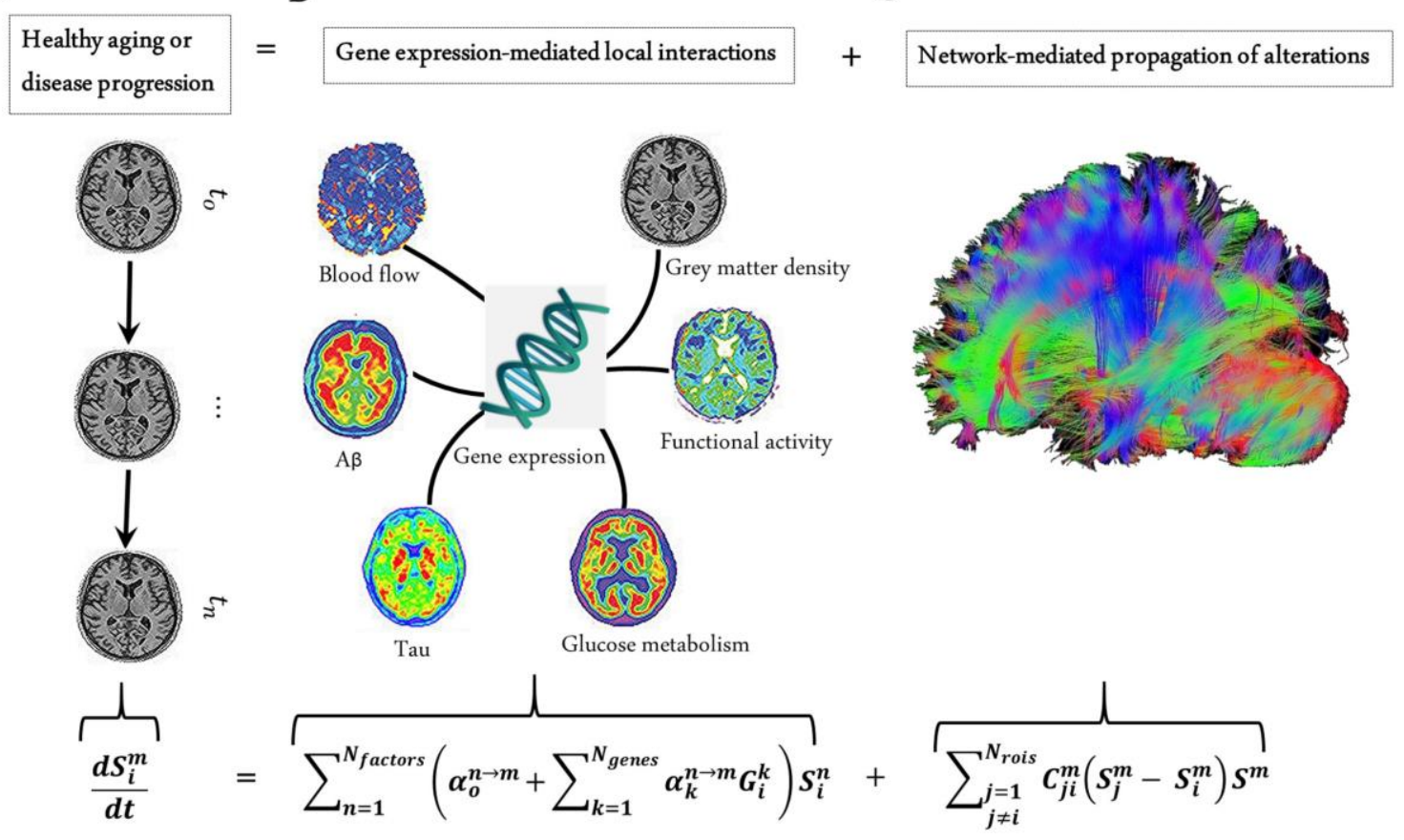

$\mathrm{D}$

Common variance between transcriptomic-imaging interactions and clinical scores
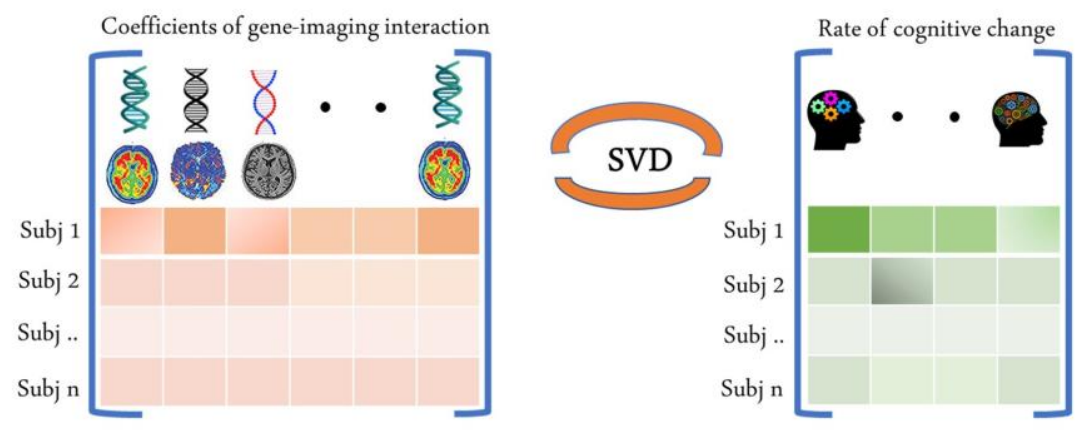

Figure 1: Modelling the gene-imaging interactions driving healthy aging and AD progression. A) The longitudinal alteration of macroscopic biological factors in healthy and diseased brain due to gene-imaging interactions and the propagation of the ensuing alterations across brain network. B) Regional multifactorial interactions between six macroscopic biological factors/imaging modalities are modulated by local gene expression. C) Causal multifactorial propagation network capturing the interregional spread of biological factor alterations through physical connections. D) By applying a multivariate analysis through singular value decomposition (SVD), the maximum cross-correlation between age-related changes in cognitive/clinical evaluation and the magnitude of genetic modulation of imaging modalities are determined in a cohort of stable healthy subjects (for healthy aging), and $\mathrm{MCl}$ converters and $A D$ subjects (for $A D$ progression). The key causal genes driving healthy aging and $A D$ 
medRxiv preprint doi: https://doi.org/10.1101/2021.02.23.21252283; this version posted March 1, 2021. The copyright holder for this preprint (which was not certified by peer review) is the author/funder, who has granted medRxiv a license to display the preprint in perpetuity. It is made available under a CC-BY-NC-ND 4.0 International license .

progression are identified through their absolute contributions to the explained common variance between the gene-imaging interactions and cognitive scores.

Next, with the complementary interest of further clarifying the genetic mechanisms underlying healthy aging and AD development, the GE-MCM framework was applied to a cohort of 151 healthy and 309 diseased subjects from ADNI (Methods, and Fig. 1). The standardized transcriptomic data was derived from 6 neurotypical brains from AHBA (Hawrylycz et al., 2012), comprising RNA intensities of 976 landmark genes with leading roles in central biological functions. These genes correspond to a set of universally informative transcripts, previously identified as "Landmark Genes" based on their capacity to cover most of the information in the whole human transcriptome across a diversity of tissue types (Subramanian et al., 2017).

The predictive performance of the model across different clinical categories is shown in Figure 2. We calculated the coefficient of determination $\left(R^{2}\right)$ of the model for the six longitudinal PET and MRI modalities, and averaged them across all subjects in each clinical group. The $R^{2}$ was highest for AD $(0.80 \pm 0.20)$, followed in order by $L M C I$ $(0.59 \pm 0.23), \mathrm{EMCl}(0.57 \pm 0.21)$ and $\mathrm{HC}(0.51 \pm 0.24)$. The improvement observed in model performance with disease progression could be due to the larger variation in biological factor alteration in the later stages of the AD continuum. Nevertheless, these results support the capacity of the GE-MCM approach to reproduce the longitudinal observations in the six molecular PET and MRI modalities. 
medRxiv preprint doi: https://doi.org/10.1101/2021.02.23.21252283; this version posted March 1, 2021. The copyright holder for this preprint (which was not certified by peer review) is the author/funder, who has granted medRxiv a license to display the preprint in perpetuity.

It is made available under a CC-BY-NC-ND 4.0 International license .

Model performance across clinical groups

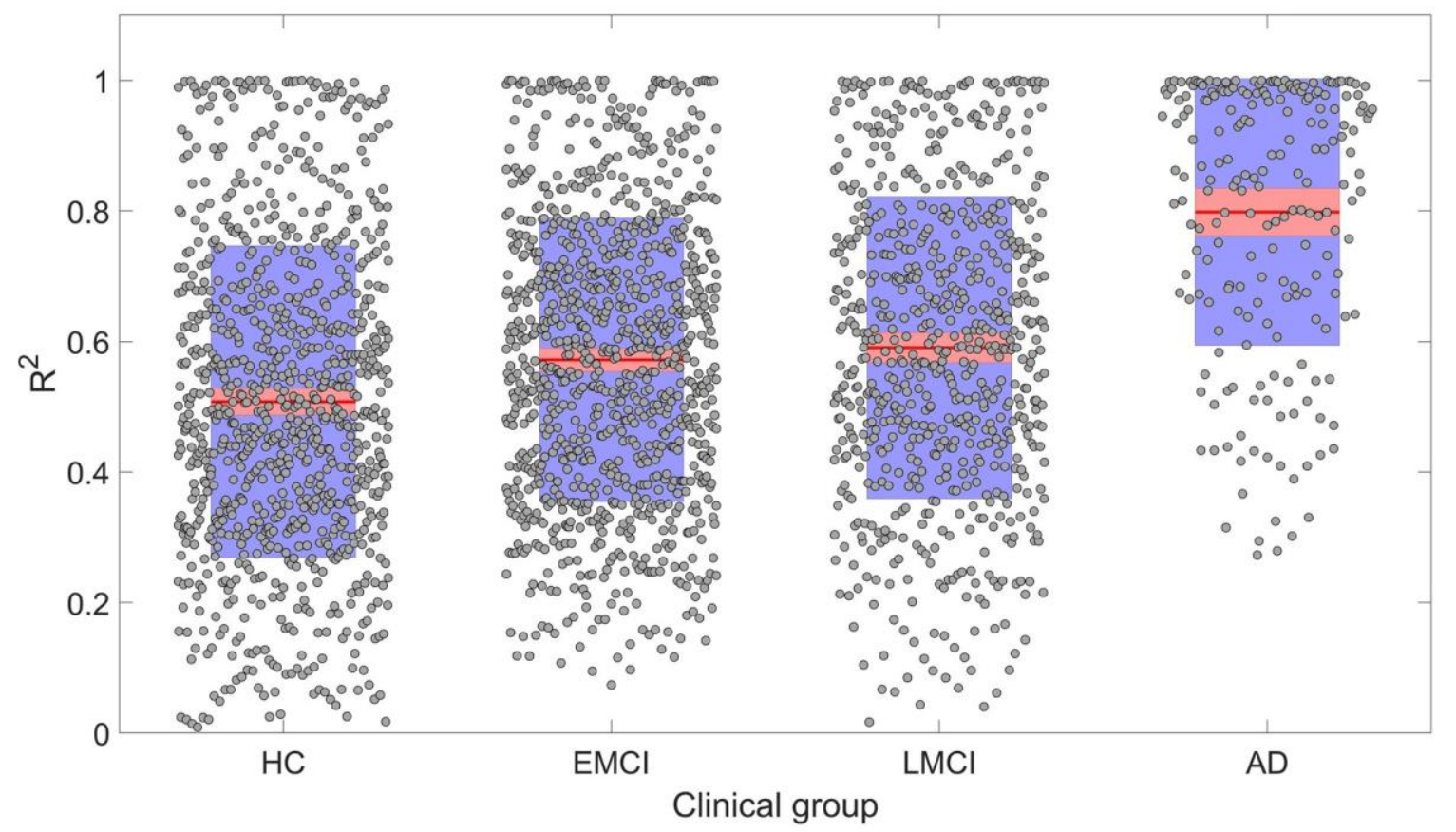

Figure 2: Reconstruction of individual multifactorial alteration patterns across all subjects in the $\mathrm{AD}$ continuum. Plots are shown for the $R^{2}$ obtained across all six biological factors in the HC ( $n=151), E M C l(n=161), L M C l(n=113)$ and AD ( $n=35)$ cohorts. Points are laid over a 2.58 standard error of the mean (SEM) (99\% confidence interval) in red and at 1 SD in blue. Notice that model performance improves with disease progression. We attribute this effect to the typical larger variation in longitudinal biological factor alterations with disease evolution, which provides the optimization algorithm with further biological information and results in a more accurate data fitting and parameters identification.

\section{Identifying Genes Driving Biological and Cognitive Changes in Healthy Aging}

Age is a significant risk factor for developing many complex disorders. Even though lifestyle and environmental factors contribute to healthy aging, understanding the genetic basis of aging will offer valuable biological insights with implications for disease prevention and longevity (Niccoli et al., 2012; Rodríguez-Rodero et al., 2011). Hence, we sought to identify causal genes underlying longitudinal cognitive changes in healthy aging. We analyzed the predictive relationship between the obtained transcriptomic-imaging parameters and multiple cognitive evaluations in $113 \mathrm{HC}$ subjects who remained clinically stable within 7.8 years ( $S D=2.9$ years). The cognitive 
medRxiv preprint doi: https://doi.org/10.1101/2021.02.23.21252283; this version posted March 1, 2021. The copyright holder for this preprint (which was not certified by peer review) is the author/funder, who has granted medRxiv a license to display the preprint in perpetuity.

It is made available under a CC-BY-NC-ND 4.0 International license.

changes were obtained as the age-related slopes of MMSE, ADAS, executive function $(E F)$, and memory score (MEM) over an average of 7.2 time points $(S D=2.6)$. For this analysis, we only used 68 stable transcriptomic-imaging parameters whose $99 \% \mathrm{Cl}$ excluded zero across the HC non-converters (see Model evaluation subsection in Methods). Using a multivariate singular value decomposition (SVD), we found the common latent variables between the gene-imaging parameters and the slopes of multiple cognitive measures, and the variances explained by the principal components (PC) are shown in Fig. 3A. Running 10000 permutations identified the first PC as the only significant component (explained variance $=50.3 \% ; P=0.0074$ ).

Next, we calculated the contribution of each gene-specific parameter on this significant PC (Model Evaluation) and assessed the statistical reliability of the genetic contributions by running 10000 bootstrap iterations. A bootstrap ratio threshold of 2.58 (approximately equivalent to $\mathrm{P}<0.01$ (Efron et al., 1986)) was applied, revealing 8 genes with stable causal contributions to the multimodal imaging dynamics and associated cognitive changes in healthy aging (Fig. 3B). Notice that the saliences of some genes are negative, implying that their modulation effects are negatively associated with the rate of cognitive change. Specifically, as shown in Figure 3C, TSKU modulates $A \beta$ while tau is modulated by GNA15 and $L S M 6$ to drive age-related alterations in A 3 . Also, BIRC5, SESN1 and PLSCR3 respectively modulate tau, CBF and $A \beta$ in driving alterations in neuronal activity. Similarly, age-related changes in tau are driven by $C 5$ and $C A S P 10$ through their direct effects on functional activity and CBF, respectively. 
medRxiv preprint doi: https://doi.org/10.1101/2021.02.23.21252283; this version posted March 1, 2021. The copyright holder for this preprint (which was not certified by peer review) is the author/funder, who has granted medRxiv a license to display the preprint in perpetuity.

It is made available under a CC-BY-NC-ND 4.0 International license .

A Proportion of variance explained by principal components

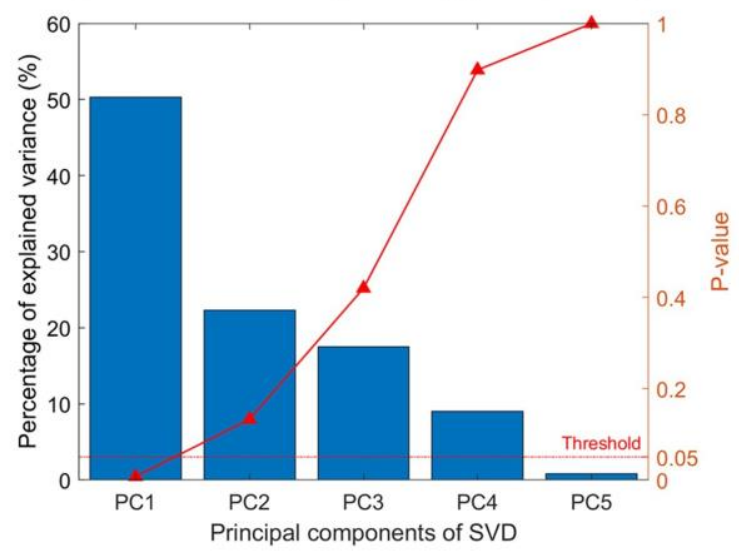

B Contributions of top causal genes in healthy aging

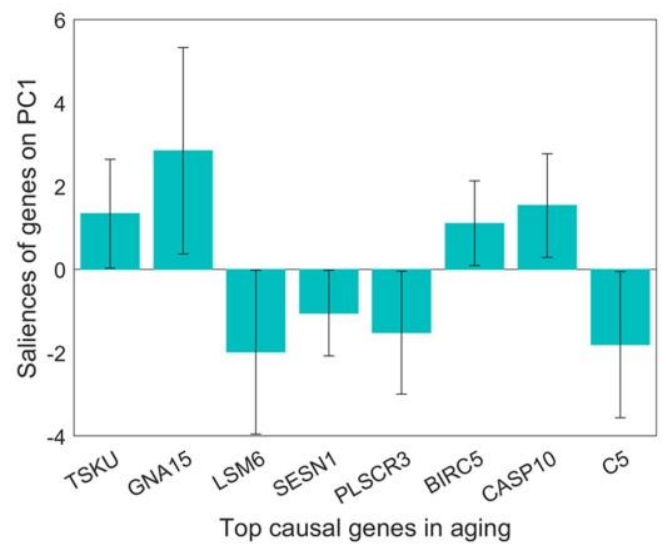

C Top aging causal genes and their macroscopic interactions

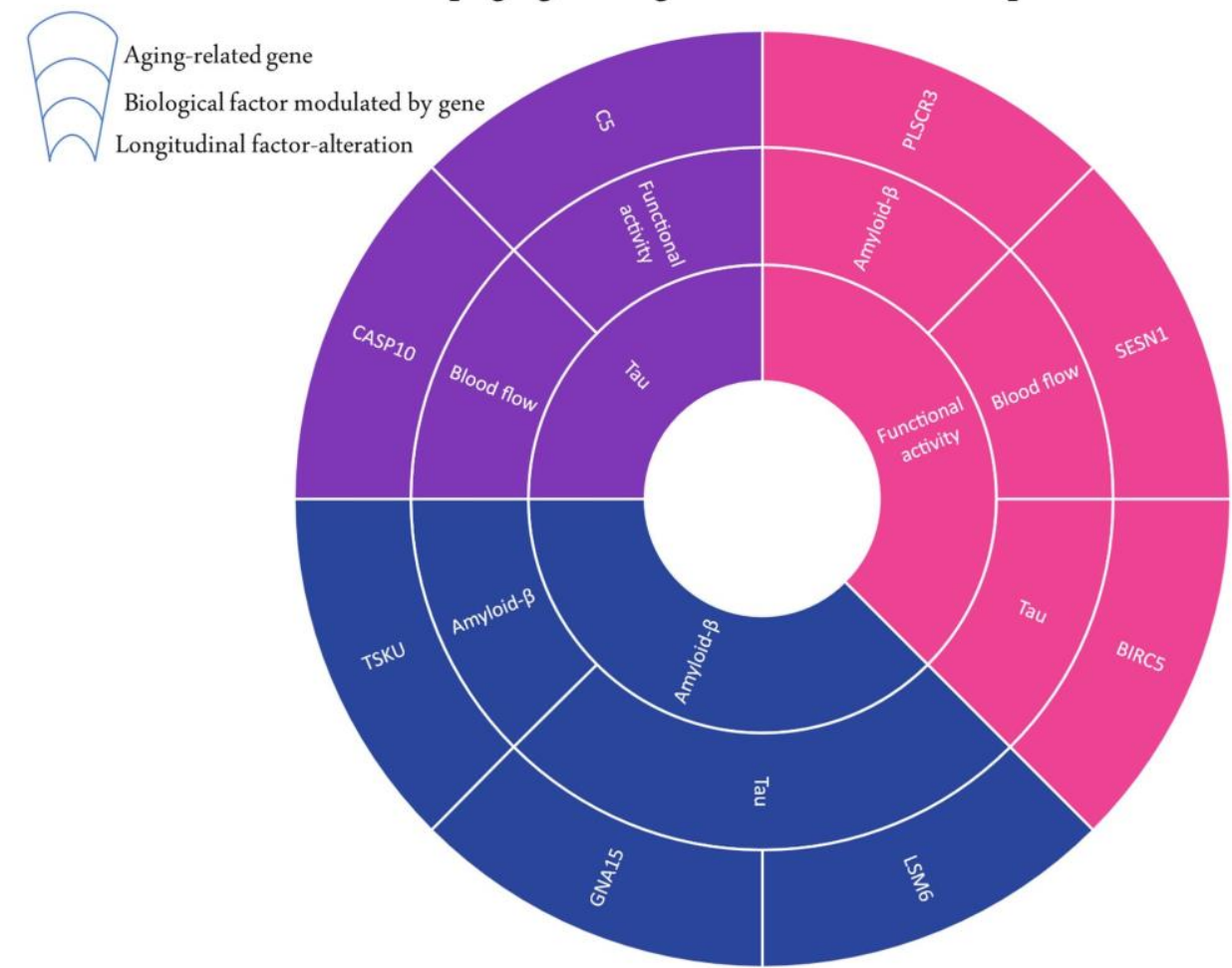

Figure 3: Identification of top genetic modulators of cognitive change in healthy aging. A) Common variance (and associated p-values) captured by the top-5 PCs of the SVD in explaining the rate of change of cognitive scores due to healthy aging. Only the first PC is significant $(\mathrm{P}<0.05)$. B) Genetic contributions (and $99 \% \mathrm{Cl}$ ) on the first $\mathrm{PC}$, depicted only for the eight highly stable aging-related genes whose bootstrap ratios are above 2.58. C) Top genetic determinants of multifactorial alterations in healthy aging. The innermost ring shows the longitudinal biological factor altered with aging, middle ring displays the interacting biological factors driving the longitudinal alteration, and the outermost ring represents the causal genes modulating the interactions among biological factors (e.g. SESN1 directly modulates blood flow to drive age-related alteration in neuronal activity). 
medRxiv preprint doi: https://doi.org/10.1101/2021.02.23.21252283; this version posted March 1, 2021. The copyright holder for this preprint (which was not certified by peer review) is the author/funder, who has granted medRxiv a license to display the preprint in perpetuity.

It is made available under a CC-BY-NC-ND 4.0 International license.

\section{Revealing Top Genes and Molecular Pathways Controlling Multifactorial} Alterations and Clinical Deterioration in $A D$

A crucial challenge for early detection and prevention of $A D$ is the development of cheap and non-invasive biomarkers (such as genes) as well as the understanding of the molecular mechanisms underlying its pathogenesis (Y. Iturria-Medina et al., 2020) . Here, we proceed to identify genes driving neuropathological progression in the $A D$ spectrum, restricting our analysis to 129 participants who were either diagnosed with $A D(35)$ at baseline or converted to AD (94) after baseline diagnosis (7 HC and 87 $\mathrm{MCl})$. Like the aging analysis, we only kept 993 statistically stable transcriptomicimaging parameters whose $99 \% \mathrm{Cl}$ excluded zero (see Model Evaluation subsection in Methods). We used SVD to obtain the common latent variables (variance) between the gene-imaging parameters and slopes of multiple cognitive measures (MMSE, ADAS, EF and MEM across 6.3 \pm 3.0 longitudinal time points). After 10000 permutation runs, the first $P C$ was significant $(P=0.009)$ and explained $63.8 \%$ of the variance between the gene-imaging interaction parameters and the slopes of cognitive evaluations (see Fig. 4A). A bootstrap ratio threshold of 2.58 (approximately equivalent to $\mathrm{P}<0.01$ (Efron et al., 1986)) was applied, identifying 111 genes (Fig. 4B) with stable causal contributions to the macroscopic factor interactions and associated cognitive changes in $A D$. The factors directly modulated by these causal genes and the ensuing factorial alterations are shown in Fig. 4C. 
A Variance explained by principal components

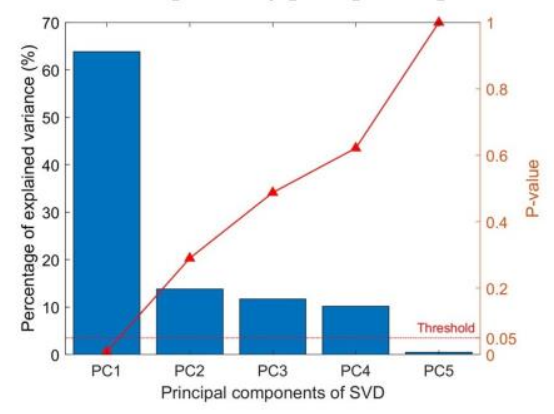

B

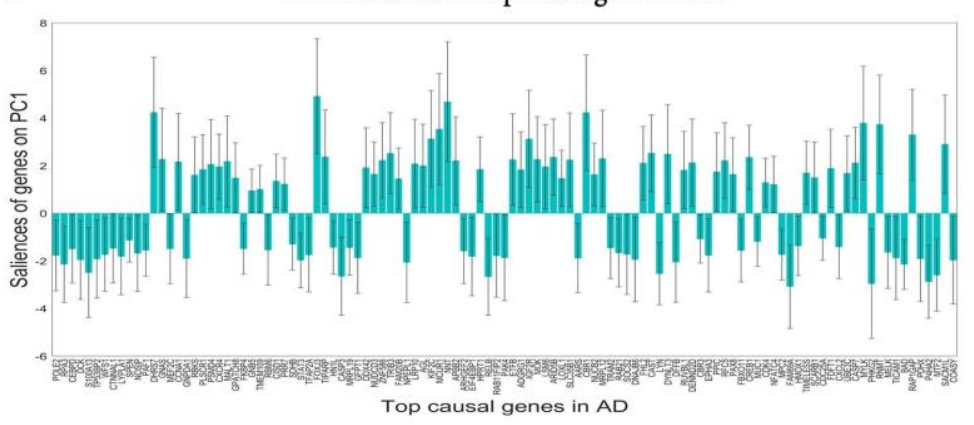

C

Top AD causal genes and their macroscopic interactions

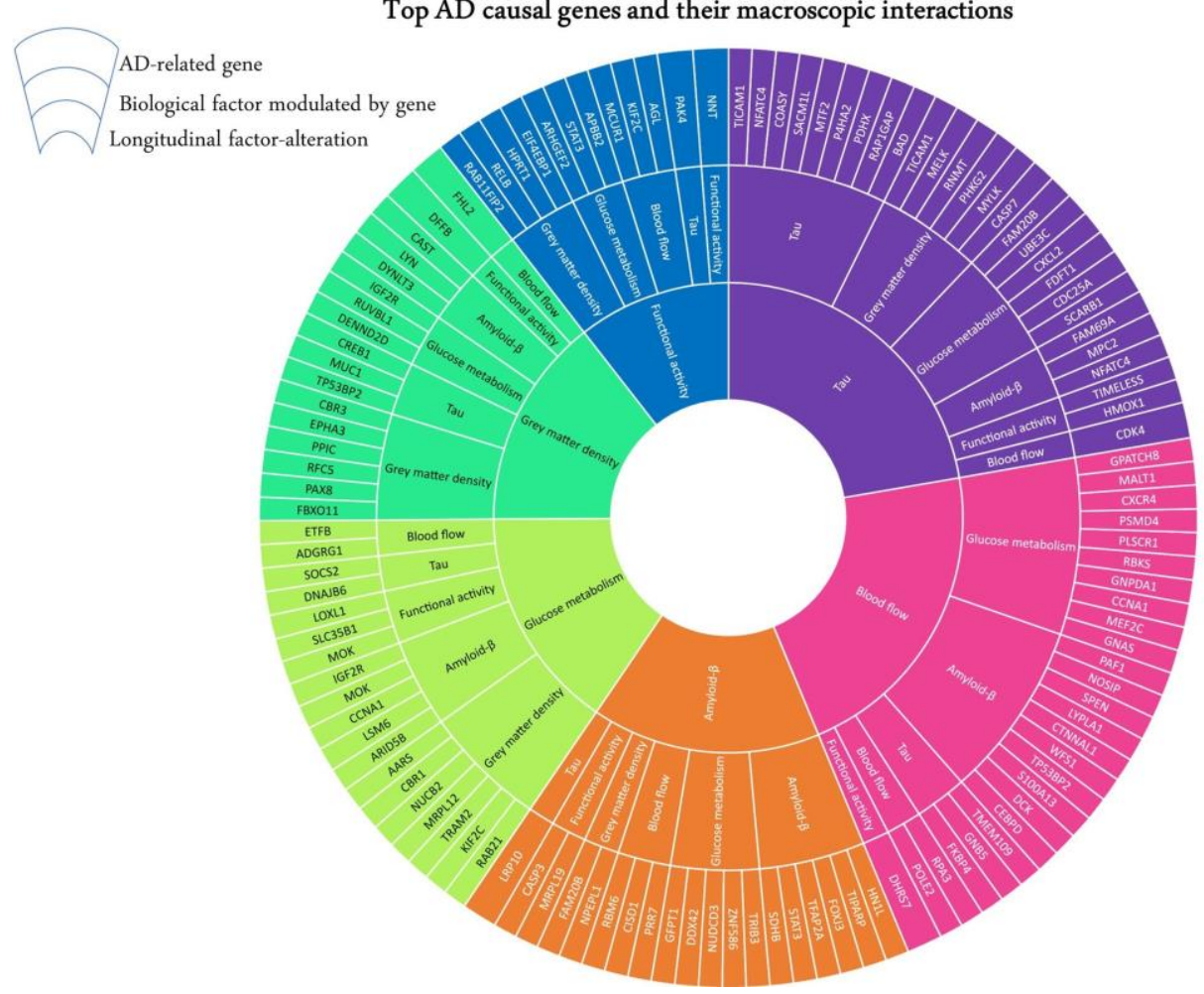

Figure 4: Uncovering the top genetic determinants of $A D$ progression. A) The common variance captured by the principal components (PCs) of the SVD in explaining how clinical evaluations change with AD evolution. P-values after 10000 permutations are also shown $B$ ) Contributions of top AD causal genes (with $99 \% \mathrm{Cl}$ ) to the first PC. Top causal genes are identified by selecting those genes whose bootstrap ratios of saliences are above 2.58. C) Multifactorial interactions between the identified genes and imaging modalities. The innermost ring shows the longitudinal biological factor changes with $A D$, middle ring displays the interacting biological factors driving the longitudinal alteration, and the outermost represents the causal genes modulating the interactions among biological factors. A gene directly influences how a biological factor interacts with other factors to cause a factorial alteration along the disease's course. 
medRxiv preprint doi: https://doi.org/10.1101/2021.02.23.21252283; this version posted March 1, 2021. The copyright holder for this preprint (which was not certified by peer review) is the author/funder, who has granted medRxiv a license to display the preprint in perpetuity.

It is made available under a CC-BY-NC-ND 4.0 International license .

Finally, we performed a large-scale gene functional analysis with PANTHER (Mi et al., 2013) to uncover the molecular pathways and biological functions associated with the 111 identified disease-driving genes. Sixty-five (65) functional pathways were identified and most of them, including Alzheimer disease-presenilin pathway, are highly representative of the biological processes commonly associated with neuropathology and cognitive decline (please see Supplementary File 5). The pathways with the leading number of genes are apoptosis, cholecystokinin receptor signalling, inflammation mediated by chemokine and cytokine, and gonadotropinreleasing hormone receptor (see Discussion).

\section{Discussion}

\section{Gene Expression Patterns Modulate Multifactorial Interactions in Healthy Aging and AD Progression}

An unprecedented attribute of this study is the insight it provides into the multiscale interactions among aging and AD-associated biological factors, and the possible mechanistic roles of the identified genetic determinants. In concordance with our results in healthy aging (see Fig. $3 \mathrm{C}$ ), BIRC5 have been shown to regulate microtubule dynamics and interact with tau (Zhao et al., 2003). Sestrins, including SESN1, preserve blood brain barrier integrity and serve a neuroprotective effect after cerebral ischemia (S.-D. Chen et al., 2019; Li et al., 2016; Shi et al., 2017). C5 belongs to the complement immune system, and it modulates synaptic pruning and plasticity by interacting with microglia. (Wang et al., 2020).

Several animal and biostatistical studies also corroborate the functional relationships observed in $A D$ results. In agreement with the interactions driving longitudinal alteration in blood flow (see Fig. 4C), FKBP4 encodes the FKBP52 protein which has been demonstrated to alter tau phosphorylation pattern and stimulate its abnormal aggregation (Giustiniani et al., 2015). FKBP52 also decreased significantly in brains of AD patients (Giustiniani et al., 2012). A bioinformatic and functional validation study identified the role of GNAS in glucose metabolism through insulin regulation (Taneera et al., 2019). Notably, several GWAS and animal studies have consistently linked MEF2C to AD and its associated cognitive decline (Beecham et al., 2014; Davies et 
medRxiv preprint doi: https://doi.org/10.1101/2021.02.23.21252283; this version posted March 1, 2021. The copyright holder for this preprint (which was not certified by peer review) is the author/funder, who has granted medRxiv a license to display the preprint in perpetuity. It is made available under a CC-BY-NC-ND 4.0 International license .

al., 2015; Lambert et al., 2013, (Sao et al., 2018)). Knocking out MEF2C in mice induced glucose metabolism impairment (Anderson et al., 2015). PLSCR1 could drive atrophy due to its apoptotic effect and interaction with calcium ion in maintaining the organization of phospholipid bilayers of membranes (Sahu et al., 2007). CXCR4 also regulates apoptosis and neuronal survival through glial signalling and the $\mathrm{Rb} / \mathrm{E} 2 \mathrm{~F}$ pathway, respectively (Bezzi et al., 2001; Khan et al., 2008) . Nitric oxide synthase interacting protein (NOSIP) controls the expression of nitric oxide synthase (NOS), the major source of nitric oxide in the brain (Dreyer et al., 2004). In brain endothelial cells, downregulating NOS upregulates APP (amyloid precursor protein) and BACE1 ( $\beta$-site APP-cleaving enzyme1) both of which control amyloid dynamics (Austin et al., 2010).

We also found congruous functional associations for the genes driving longitudinal alterations in A . Apart from its apoptotic role, CASP3 has been shown to regulate synaptic plasticity and functional activity in vivo (D'Amelio et al., 2010). TRIB3 controls glucose metabolism, insulin signalling and the expression of other glucose metabolism genes ((Prudente et al., 2012; W. Zhang et al., 2013; W. Zhang et al., 2016). Among the genes altering tau with $A D$ progression, nuclear factor of activated T cells (NFAT) overexpression in animal model increased $A \beta$ production and promoted BACE1 transcription (Mei et al., 2015). TIMELESS (TIM) is a gene with central role in controlling circadian neuronal activity (Kurien et al., 2019). Interestingly, dysregulated circadian rhythm is causally associated with AD (Homolak et al., 2018). Furthermore, our results on glucose metabolism dysregulation align with previous functional studies. RAB21 may induce atrophy through apoptosis and cell growth inhibition (Ge et al., 2017). Due to its function in detoxifying reactive aldehydes produced from lipid peroxidation, the carbonyl reductase enzyme $C B R 1$ could prevent oxidative stressinduced atrophy (Maser, 2006). DNAJ proteins belong to the group of chaperones that regulate protein homeostasis, and an earlier study implicated DNAJB6 in a-synuclein aggregation (Aprile et al., 2017). Investigating the effect DNAJB6 on tau processing as suggested by our result could provide further insight into the roles of the gene of AD.

Supporting our results for longitudinal alterations in functional activity, downregulating EIF4EBP1 prevents toxin-induced neuronal atrophy in PD model by blocking the action of apoptotic caspsase-3 (Xu et al., 2014). The gene also mediates synaptic reorganization and refinement, independent of post synaptic activity (Chong et al., 
medRxiv preprint doi: https://doi.org/10.1101/2021.02.23.21252283; this version posted March 1, 2021. The copyright holder for this preprint (which was not certified by peer review) is the author/funder, who has granted medRxiv a license to display the preprint in perpetuity.

It is made available under a CC-BY-NC-ND 4.0 International license.

2018). Even though APBB2 (amyloid beta A4 precursor protein-binding, family $\mathrm{B}$, member 2) primarily binds to $A P P$, knocking out $A P B B 2$ in mice causes glucose intolerance and $\beta$ cell dysfunction (Ye et al., 2018). In transgenic mice, deleting STAT3 in $\beta$ cells and neurons impaired glucose metabolism (Cui et al., 2004). It also regulates liver glucose homeostasis by modulating the expression of gluconeogenic genes (Inoue et al., 2004). A gene co-regulatory network analysis identified RAB11FIP2 as a differentially expressed gene in axon regeneration, suggesting its possible role in atrophy (Su et al., 2018). Correspondingly, a growing body of evidence supports the gene-imaging interactions we found in longitudinal alterations in atrophy. CAST overexpression was shown to reduce amyloid burden due to its effect on BACE1 processing of APP (Liang et al., 2010; Morales-Corraliza et al., 2012). FHL2 prevents inflammatory angiogenesis and regulates the function of vascular smooth muscle cells, suggesting its role in blood flow (C. Y. Chen et al., 2020; Chu et al., 2008). IGF2R (insulin-like growth factor 2 receptor) interacts with insulin receptors for energy homeostasis, and the dysregulation of the gene is associated with type 2 diabetes (Chanprasertyothin et al., 2015). RUVBL1 is an ATPase which modulates insulin signalling, and RUVBL1 knock-out mice displayed impaired glucose metabolism (Mello et al., 2020).

\section{Aging and Alzheimer's Disease Have Both Common and Distinct Mechanisms}

In this study, we used a single gene expression template for all the subjects due to the unavailability of individual whole-brain gene expression. However, notice that even though this template has spatial but no temporal variation, for each gene, a model parameter controls its interaction (at the individual level) with each time-varying neuroimaging modality (i.e. the estimated transcriptomic-imaging parameters). At the individual level, the fitted gene-imaging parameters are assumed to reflect the genespecific deformations required to fit the data. Consequently, these parameters represent quantitative measures of the individual dysregulation or deviation in gene expression patterns; and when analyzed across the entire population (e.g. via SVD analysis), the parameters can be used to detect cognitive/clinical related genetic associations." Thus, under normal aging, the parameters obtained from the model optimization should be close to zero. Interestingly, it was observed that only $\sim 70$ 
medRxiv preprint doi: https://doi.org/10.1101/2021.02.23.21252283; this version posted March 1, 2021. The copyright holder for this preprint (which was not certified by peer review) is the author/funder, who has granted medRxiv a license to display the preprint in perpetuity.

It is made available under a CC-BY-NC-ND 4.0 International license .

parameters (out of over 35000 gene-imaging interaction parameters) were significantly different from zero across the healthy aging population. Conversely, 1000 parameters significantly differed from zero across the diseased population. We attribute the greater number of significant parameters in $A D$ to more genetic dysregulations and biological mechanism alterations in the disorder (Y. Iturria-Medina et al., 2020; Mostafavi et al., 2018).

The mechanisms of healthy aging and AD substantially overlap even though ADrelated alterations are often accelerated, and the regions of alteration could be different (Toepper, 2017; Xia et al., 2018). Among the aging-associated genes, CASP10, BIRC5, and PLSCR3 are involved in caspase-dependent apoptosis. Interestingly, apoptotic genes were also found in AD including CASP3, CASP7, PLSCR1, CREB1, RELB, IGF2R, DFFB. Sestrin (SESN1) is implicated in oxidative signalling, aging inhibition, and exercise mediation (Budanov et al., 2010; M. Kim et al., 2020; Yang et al., 2013). Correspondingly, some AD causal genes including MEF2C, CBR1 and NOSIP are known for their roles in oxidative stress, supporting the relevance of this pathway to both normal and pathological aging (Y. N. Kim et al., 2014; Rochette et al., 2013). Given that G-protein coupled receptors (GPCR) mediate the cellular response to most hormones/neurotransmitters (de Oliveira et al., 2019; Thathiah et al., 2011), it is unsurprising that GPCR-related genes converge on normal aging (GNA15) and Alzheimer's disease (GNAS, GNB5). Having found some inflammation-associated genes in $A D$ and the complement component $C 5$ in aging suggests that immune/inflammatory response change is part of both healthy aging and AD. Indeed, apart from the overlapping pathways, LSM6 was the only gene common to both normal aging and AD. LSM6 regulates gene expression and mRNA splicing, and a proteomic study linked its expression level to aging in human muscle cells (Ubaida-Mohien et al., 2019). Although altered mRNA splicing is associated with AD (Erik C. B. Johnson et al., 2018; Koch, 2018; Twine et al., 2011), a functional validation can further reveal the exact role of LSM6 in the disease. 
medRxiv preprint doi: https://doi.org/10.1101/2021.02.23.21252283; this version posted March 1, 2021. The copyright holder for this preprint (which was not certified by peer review) is the author/funder, who has granted medRxiv a license to display the preprint in perpetuity.

It is made available under a CC-BY-NC-ND 4.0 International license .

\section{Towards a Genetic Approach to Extending Healthy Aging and Treating}

\section{Alzheimer's Disease}

The complexity of aging and the mixed aetiology of neurodegeneration necessitate an integrative multifactorial paradigm. In this study, we advanced the understanding of aging and $A D$ pathology through the mechanistic modelling of how gene activity modulates relevant biological factors (e.g. tau, $A \beta, C B F$, neuronal activity) to drive the cognitive alterations typically observed in the associated populations. The obtained results, in line with relevant molecular and imaging literature, highlight the strength of our approach by confirming previously identified aging- and AD-associated genes and uncovering new genes with relevant pathophysiological roles. In essence, this flexible formulation directly decodes the genetic mediators of spatiotemporal macroscopic brain alterations with aging and disease progression. Consequently, this work has important implications for the mechanistic understanding of aging and $A D$ pathogenesis and, importantly, for the implementation of a biologically defined patient stratification for personalized medical care.

Current approaches to $A D$ treatment do not account for patient heterogeneity and such non-personalized methods may not only be ineffective but also cause undesired secondary effects in patients (Iturria-Medina et al., 2018). In a previous study, we used a similar imaging-based framework to show that some patients may need interventions targeting either tau, $\mathrm{A} \beta, \mathrm{CBF}$ or metabolism, while others can require a combinatorial therapy (e.g. concurrently targeting tau, $A \beta$, and metabolic dysregulation) (IturriaMedina et al., 2018). Based on this extended approach (GE-MCM), a gene therapy could replace the single and combinatorial treatment fingerprints described, by targeting highly influential genes modulating those factors in individuals. Many of the gene-imaging relationships found in our study have been previously reported in vivo, and the novel associations can be validated through experimental models. Understanding these relationships is crucial for effective drug development and administration. For instance, we found that $A P B B 2$ is mediator of glucose metabolism. Thus, metabolic side effects may be considered when selecting APBB2 as a therapeutic target of amyloid processing.

We have used inferred mRNA values for unobserved regions due to the unavailability of high-spatial resolution GE data. Nevertheless, the correlations between observed 
medRxiv preprint doi: https://doi.org/10.1101/2021.02.23.21252283; this version posted March 1, 2021. The copyright holder for this preprint (which was not certified by peer review) is the author/funder, who has granted medRxiv a license to display the preprint in perpetuity.

and predicted mRNA values are very high for majority of the genes (see Figure 1figure supplement 2), further supporting the feasibility of interpolating mRNA values based on spatial dependence (Gryglewski et al., 2018). It is however noteworthy that some genes with low correlation values might have low spatial dependence or error in the assay. There is inherent bias in the merged gene expression data from AHBA due to individual variability, and the AHBA subjects are not very representative of the typical age range in the ADNI cohort. Nevertheless, animal and human studies have reported large concordance between peripheral and brain gene expression, implying that blood gene expression may be used as a surrogate for gene expression in brain tissue (Y. Iturria-Medina et al., 2020; Jasinska et al., 2009; Sullivan et al., 2006; Witt et al., 2013). Thus, our future work will therefore focus on using personalized gene expression data from blood samples. The applicability and generalizability of the current formulation would also be tested in other neurological conditions (e.g. Parkinson's disease and frontotemporal dementia).

\section{Materials and Methods}

\section{Data Description and Processing}

\section{Study Participants}

This study involved 944 individuals with six multimodal brain imaging from the Alzheimer's Disease Neuroimaging Initiative (ADNI, RRID:SCR_003007) (adni.loni.usc.edu; see Figure 1 - figure supplement 1). First, for each imaging modality, a multivariate outlier identification was performed based on the Mahalanobis distance, with a significant squared distance $(P<0.05)$ denoting an outlier (Iturria-Medina et al., 2016). From the 911 subjects that survived outlier detection, we chose 509 subjects having at least four imaging modalities (between amyloid PET, tau PET, glucose metabolism PET, resting state fMRI, cerebral blood flow ASL, and structural MRI). Then, 460 subjects with at least three time points in any of the imaging modalities were selected for our analyses. Next, for each of these subjects $(N=460)$, missing imaging modalities at each time point having actual individual data were automatically imputed using the trimmed scores regression with internal PCA (Folch-Fortuny et al., 2016). The accuracy of the imputation was validated with a leave-one-out cross-validation 
medRxiv preprint doi: https://doi.org/10.1101/2021.02.23.21252283; this version posted March 1, 2021. The copyright holder for this preprint (which was not certified by peer review) is the author/funder, who has granted medRxiv a license to display the preprint in perpetuity.

(e.g. tau imaging data can be significantly recovered for each subject with actual data, $\left.P<10^{-6}\right)$. Hence, all the 460 subjects used in subsequent analyses have completed all six neuroimaging modalities and average of $4.7( \pm 2.5)$ longitudinal time points. Please see Figure 1-figure supplement 1 for a detailed flowchart of subject selection, and Supplementary File 1 for demographic characteristics. Among the 460 participants, 151 were clinically identified as asymptomatic or healthy control $(\mathrm{HC}), 161$ with early mild cognitive impairment (EMCI), 113 with late mild cognitive impairment (LMCI) and 35 with probable Alzheimer's disease (AD).

\section{Whole-Brain Gene Expression Data and Brain Parcellation}

Microarray data was downloaded from the Allen Human Brain Atlas (AHBA, RRID:SCR_007416) website (www.brain-map.org)(Hawrylycz et al., 2012). The AHBA data consists of mRNA expression in 3702 tissue samples obtained from 6 neurotypical adult brains. The data were preprocessed by the Allen Institute to reduce the effects of bias due to batch effects. Description of the processing steps can be found in the technical white paper (Allen Human Brain Atlas, 2013). For each brain, there are 58,692 probes representing 20,267 unique genes. Transcriptome shows spatial dependence, with adjacent regions having similar expression patterns values (Gryglewski et al., 2018). Gaussian kernel regression affords a method of predicting gene expression values for unobserved regions based on the mRNA values of proximal regions. The regression is done as a weighted linear combination of unobserved mRNA, with the weight decreasing outward from proximal to distal regions. In order to select a representative probe for genes with multiple probes, Gaussian kernel regression was applied to predict the mRNA intensity in each of the 3702 samples in MNI space (Evans et al., 1994) using leave-one-out cross-validation. The probe with the highest prediction accuracy (among the multiple probes for a gene) was chosen as the representative probe for that gene. Next, because GE values were not available for all the grey matter voxels of the brain, Gaussian kernel regression was also used to predict the GE for the remaining MNI coordinates without mRNA expression intensity. Hence, a whole brain GE data was obtained for the selected 20267 probes/genes. It was infeasible to use these 20000 AHBA genes for modelling, hence we selected 976 AHBA genes that can be found in the list of 978 landmark genes identified by (Subramanian et al., 2017). These landmark genes are universally 
medRxiv preprint doi: https://doi.org/10.1101/2021.02.23.21252283; this version posted March 1, 2021. The copyright holder for this preprint (which was not certified by peer review) is the author/funder, who has granted medRxiv a license to display the preprint in perpetuity.

It is made available under a CC-BY-NC-ND 4.0 International license .

informative transcripts with the capacity to cover most of the information in the whole human transcriptome across a diversity of tissue types (see Supplementary File 2).

The brain was parcellated into 144 grey matter regions and the average expression value of each gene was calculated for each region. The brain parcellation was derived from a combination of two atlases: 88 regions were identified through cytoarchitecture from Julich atlas (Palomero-Gallagher et al., 2019) and 56 regions were derived from Brodmann atlas. Six regions were excluded due to zero or strong outlier PET imaging signals in their volumes. The remaining 138 regions were used for analyses (see Supplementary File 3).

\section{Cognitive and Clinical Evaluations}

The participants were characterized cognitively using the mini-mental state examination (MMSE), memory composite score (MEM), executive function composite score (EF) (Gibbons et al., 2012), and Alzheimer's Disease Assessment ScaleCognitive Subscales 11 and 13 (ADAS-11 and ADAS-13, respectively). They were also clinically diagnosed at baseline as healthy control $(\mathrm{HC})$, early mild cognitive impairment $(\mathrm{EMCl})$, late mild cognitive impairment $(\mathrm{LMCl})$ or probable Alzheimer's disease patient (AD).

\section{Multimodal Imaging Modalities}

ASL MRI: Resting Arterial Spin Labeling (ASL) data were acquired using the Siemens product PICORE sequence $(\mathrm{N}=213)$ with acquisition parameters as: TR/TE $=3400 / 12 \mathrm{~ms}, \quad$ TI1/TI2 $=700 / 1900 \mathrm{~ms}, \quad F O V=256 \mathrm{~mm}, 24$ sequential $4 \mathrm{~mm}$ thick slices with a $25 \%$ gap between the adjacent slices, partial Fourier factor $=6 / 8$, bandwidth $=2368 \mathrm{~Hz} /$ pix , and imaging matrix size $=64 \times 64$. The data were processed in six steps as follows: 1) motion correction, 2) perfusion-weighted images (PWI) computation, 3) intensity scaling, 4) CBF images calculation, 5) spatial normalization to $\mathrm{MNI}$ space (Evans et al., 1994) using the registration parameters obtained for the structural T1 image with the nearest acquisition date, and 6) mean CBF calculation for each of the considered brain regions. Details of the processing can be found at www.adni.loni.usc.edu under "UCSF ASL Perfusion Processing Methods".

Amyloid- $\beta$ (Aß) PET: A 370-MBq bolus injection of AV-45 was administered to each subject, and after about 50 minutes, 20-minute continuous brain PET imaging scans 
medRxiv preprint doi: https://doi.org/10.1101/2021.02.23.21252283; this version posted March 1, 2021. The copyright holder for this preprint (which was not certified by peer review) is the author/funder, who has granted medRxiv a license to display the preprint in perpetuity.

It is made available under a CC-BY-NC-ND 4.0 International license .

were acquired $(\mathrm{N}=459)$. The images were reconstructed immediately after the scan, and when motion artifact was detected, another 20-minute continuous scan was acquired. The acquired PET scans were then preprocessed in four main steps described in (Jagust et al., 2010): 1) dynamic co-registration to reduce motion artifacts 2) across time averaging, 3) re-sampling and reorientation of scans from native space to a standard voxel image grid space ("AC-PC" space), and 4) spatial filtering to convert the mages to a uniform isotropic resolution of $8 \mathrm{~mm}$ FWHM. Finally, using the registration parameters obtained for the structural $\mathrm{T} 1$ image with the nearest acquisition date, all $A \beta$ scans were transformed to the MNI space (Evans et al., 1994). Using the cerebellum as an $A \beta$ non-specific binding reference, SUVR values were calculated for the 138 brain regions under consideration.

Resting-state fMRI: Resting-state fMRI scans were acquired using an echo-planar pulse sequence on a 3.0T Philips MRI scanner $(N=148)$ with the following parameters: 140 time points, repetition time $(T R)=3000 \mathrm{~ms}$, echo time $(T E)=30 \mathrm{~ms}$, flip angle $=80^{\circ}$, number of slices $=48$, slice thickness $=3.3 \mathrm{~mm}$, spatial resolution $=3 \times 3 \times 3 \mathrm{~mm}^{3}$, and in-plane matrix size $=64 \times 64$. The scans were corrected for motion and slice timing. Then, they were spatially normalized to $\mathrm{MNI}$ space (Evans et al., 1994) using the registration parameters obtained for the structural T1 image with the nearest acquisition date. Signal filtering was performed to retain only low frequency fluctuations $(0.01-0.08 \mathrm{~Hz})$ (Chao-Gan et al., 2010). Fractional amplitude of low-frequency fluctuation (fALFF) was calculated and used a regional quantitative indicator of the brain's functional integrity. fALFF has been shown to be highly sensible to disease progression (Iturria-Medina et al., 2016).

Fluorodeoxyglucose PET: A 185-MBq $(5+0.5 \mathrm{mCi})$ of [18F]-FDG was administered to each subject and brain PET imaging data were obtained approximately 20 minutes after injection $(\mathrm{N}=455)$. The images were attenuation-corrected and then preprocessed as follows (Jagust et al., 2010): 1) dynamic co-registration of frames to reduce the effects of patient motion 2) across time averaging, 3) reorientation from native space to a standard voxel image grid ("AC-PC"), and 4) spatial filtering to convert the mages to a uniform isotropic resolution of $8 \mathrm{~mm}$ FWHM. Next, using the registration parameters obtained for the structural $\mathrm{T} 1$-weighted image with nearest acquisition date, the FDG-PET images were normalized to the MNI space (Evans et 
medRxiv preprint doi: https://doi.org/10.1101/2021.02.23.21252283; this version posted March 1, 2021. The copyright holder for this preprint (which was not certified by peer review) is the author/funder, who has granted medRxiv a license to display the preprint in perpetuity.

It is made available under a CC-BY-NC-ND 4.0 International license .

al., 1994). The cerebellum was then used as a reference to calculate standardized uptake value ratio (SUVR) values for the 138 regions (Klein et al., 2012).

Structural MRI: Structural T1-weighted 3D images were obtained for all subjects ( $\mathrm{N}=460)$ as described in http://adni.loni.usc.edu/methods/documents/mri-protocols/. The images were corrected for intensity nonuniformity using the N3 algorithm (Sled et al., 1998). Next, they were segmented into grey matter (GM), white matter (WM) and cerebrospinal fluid (CSF) probabilistic maps, using SPM12 (www.fil.ion.ucl.ac.uk/spm). The grey matter segmentations were transformed into MNI space (Evans et al., 1994) using DARTEL (Ashburner, 2007). To preserve the initial amount of tissue volume, each map was corrected for the effects of the spatial registration. Mean grey matter density and determinant of the Jacobian (DJ) (Ashburner, 2007) values were calculated for 138 regions covering all the brain's grey matter (Klein et al., 2012). The grey matter density was used in this study as a measure of structural atrophy.

Tau PET: A $370-\mathrm{MBq} / \mathrm{kg}$ bolus injection of tau specific ligand ${ }^{18} \mathrm{~F}-\mathrm{AV}-1451$ ([F- 18] T807) was given to each subject, and 30 -minute $(6 \times 5$ min frames) brain PET scans were acquired at 75 minutes after injection $(\mathrm{N}=233)$. As described (Jagust et al., 2010), the images were preprocessed by: 1) dynamic co-registration 2) across time averaging, 3) re-sampling and reorientation from native space to a standard voxel image grid space ("AC-PC" space), and 4) spatial filtering to obtain images of a uniform isotropic resolution of $8 \mathrm{~mm}$ FWHM. Next, using the registration parameters obtained for the structural T1 image with the nearest acquisition date, all tau images were normalized to the MNI space (Evans et al., 1994). The cerebellum was used as a reference to calculate SUVR values for the 138 grey matter regions.

\section{Anatomical Connectivity Estimation}

The connectivity matrix was constructed in DSI Studio (http://dsi-studio.labsolver.org) using a group average template from 1065 subjects (Yeh et al., 2018). A multi-shell high angular resolution diffusion scheme was used, and the b-values were 990, 1985 and $2980 \mathrm{~s} / \mathrm{mm}^{2}$. The total number of sampling directions was 270 . The in-plane resolution and slice thickness were $1.25 \mathrm{~mm}$. The diffusion data were reconstructed in the $\mathrm{MNI}$ space using q-space diffeomorphic reconstruction to obtain the spin distribution function (Yeh et al., 2011; Yeh et al., 2010). The sampling length and 
medRxiv preprint doi: https://doi.org/10.1101/2021.02.23.21252283; this version posted March 1, 2021. The copyright holder for this preprint (which was not certified by peer review) is the author/funder, who has granted medRxiv a license to display the preprint in perpetuity.

It is made available under a CC-BY-NC-ND 4.0 International license .

output resolution were set to 2.5 and $1 \mathrm{~mm}$, respectively. The restricted diffusion was quantified using restricted diffusion imaging (Yeh et al., 2017) and a deterministic fibre tracking algorithm was used (Yeh et al., 2013). Using the brain atlas previously described under Methods: Whole-Brain Gene Expression Data and Brain Parcellation, seeding was placed on the whole brain while setting the QA threshold to 0.15 . The angular threshold was randomly varied from 15 to 90 degrees and the step size from 0.5 voxel to 1.5 voxels. The fibre trajectories were smoothed by averaging the propagation direction with a percentage of the previous direction, which was randomly selected from $0 \%$ to $95 \%$. Tracks with length shorter than $30 \mathrm{~mm}$ or longer than 300 $\mathrm{mm}$ were then discarded. A total of 100000 tracts were calculated and connectivity matrix was obtained by using count of the connecting tracks.

\section{Gene Expression Multifactorial Causal Model (GE-MCM)}

In the basic MCM formulation (Iturria-Medina et al., 2017), the brain is considered as a dynamic multifactorial causal system, where: i) each variable represents a relevant macroscopic biological factor at a given brain region (e.g. tau and amyloid proteins, $\mathrm{CBF}$, neuronal activity at rest, grey matter density), and ii) alterations in each biological factor are caused by direct factor-factor interactions, the intra-brain propagation of factor-specific alterations (e.g. tau and amyloid spreading), and external inputs (e.g. drugs). Here, we extend this approach to incorporate GE at the regional level. Specifically, we examine how macroscopic biological alterations at each brain region, and the associated macroscopic factor-factor interactions, are controlled by the regional genetic activity.

The GE-MCM is therefore defined by: (i) the influence of each gene on the local direct interactions among all the macroscopic factors, constrained within each brain region, and (ii) the potential spreading of macroscopic factor-specific alterations through anatomical and/or vascular networks. Mathematically, these processes can be described as:

$\frac{d S_{i}^{m}}{d t}=\sum_{n=1}^{N_{\text {factors }}}\left(\alpha_{o}^{n \rightarrow m}+\sum_{k=1}^{N_{\text {genes }}} \alpha_{k}^{n \rightarrow m} G_{i}^{k}\right) S_{i}^{n}+\sum_{\substack{j=1 \\ j \neq i}}^{N_{\text {rois }}} C_{j i}^{m}\left(S_{j}^{m}-S_{i}^{m}\right) S^{m}$ 
medRxiv preprint doi: https://doi.org/10.1101/2021.02.23.21252283; this version posted March 1, 2021. The copyright holder for this preprint (which was not certified by peer review) is the author/funder, who has granted medRxiv a license to display the preprint in perpetuity.

$N_{\text {genes }}=976$ is the number of genes. Each gene was normalized by z-score across $N_{\text {rois }}=138$ brain grey matter regions of interest (a gene $i$ is denoted as $G_{i}$; for region names, see Supplementary File 3 ). $N_{\text {factors }}=6$ is the number of biological factors measured at the same brain regions (i.e. $A \beta$ deposition, tau deposition, $C B F$, glucose metabolism, functional activity at rest, and grey matter density). Each node, corresponding to a given biological factor $m$ and region $i$, is characterized by $S_{i}^{m} \in \mathbb{R}$.

In the equation, $\frac{d s_{i}^{m}}{d t}$ is the local longitudinal alteration of a macroscopic factor $m$ at region $i$, because of the foregoing multiscale interactions. The first term on the right models the local direct influences of multiple macroscopic biological factors on the given factor $m$. The interaction parameters $\left(\alpha_{o}^{n \rightarrow m}, \alpha_{k}^{n \rightarrow m}\right)$ and gene expression $\left(G_{i}^{k}\right)$ modulate the direct within-region impact of the factor $n$ on $m$, including intra-factor effects, i.e. when $n=m . \sum_{\substack{j=1 \\ j \neq i}}^{N_{\text {rois }}} C_{j i}^{m}\left(S_{j}^{m}-S_{i}^{m}\right) S^{m}$ reflects the resultant signal propagation of factor $m$ from region $i$ to other brain regions through the physical network $C_{j i}^{m}$.

The GE-MCM model can advance our mechanistic understanding of the complex processes of aging and neurodegeneration. Its ability to map a healthy gene expression template to each subject allows us to model how the spatial distribution of transcriptome drives the multifactorial alteration observed in the brain. The interaction parameter $\alpha_{k}^{n \rightarrow m}$ is an implicit quantitative measure of dysregulation or deviation of gene expression from normal patterns. By fitting the model at the individual level, it is possible to identify subject-specific genetic targets for personalized treatment of $A D$ and enhancing healthy aging.

\section{Model Evaluation}

The GE-MCM differential equation (1) was solved for each participant. For each subject $j$ and biological factor $m, \frac{d s_{i}^{m}(j)}{d t}$ was calculated between each pair of consecutive time points, and the regional values obtained were concatenated into a subject- and factor-specific vector $\left(\frac{d s^{m}(j)}{d t}\right)$ with $N_{\text {rois }} \cdot\left(N_{\text {times }}-1\right)$ unique values. This concatenation allowed us to express the evaluation of the model parameters ( $\alpha_{o}^{n \rightarrow m}$, $\alpha_{k}^{n \rightarrow m}$ ) as a regression problem (with $\frac{d s^{m}(j)}{d t}$ as dependent variable). We applied a 
medRxiv preprint doi: https://doi.org/10.1101/2021.02.23.21252283; this version posted March 1, 2021. The copyright holder for this preprint (which was not certified by peer review) is the author/funder, who has granted medRxiv a license to display the preprint in perpetuity.

It is made available under a CC-BY-NC-ND 4.0 International license .

Bayesian sparse linear regression with horseshoe hierarchy to identify the distribution of the model parameters (Carvalho et al., 2010; Makalic et al., 2016). Due to high dimensionality of the data, a computationally efficient algorithm was used to sample the posterior Gaussian distribution of the regression coefficients (Bhattacharya et al., 2016), and the algorithm was implemented in MATLAB (Makalic et al., 2016). Through Markov chain Monte Carlo, we generated 500 samples of each regression coefficient after discarding the first 1000 burn-in simulations. All 500 samples were averaged, and 5863 coefficients were obtained for every subject and biological factor. For subsequent analysis, we used 5856 coefficients (transcriptomic-imaging parameters) that corresponded to the measure of transcriptomic effect on the interaction of a macroscopic imaging-based factor with the other macroscopic factors, in driving a longitudinal biological factor alteration.

Next, we sought to identify the top genes mediating cognitive and behavioural changes in healthy aging and AD progression. First, we identified 113 clinically stable HC subjects who did not convert to $\mathrm{MCl}$ or $\mathrm{AD}$ stage within $7.8 \pm 2.9$ years. In addition, we selected 129 diseased subjects diagnosed with $A D$ at baseline or AD converters (i.e. $\mathrm{HC}$ and $\mathrm{MCl}$ subjects that advanced to $\mathrm{AD}$ within $3.7 \pm 2.9$ years). For each independent subset of subjects (i.e. stable HC or diseased subjects), we combined the transcriptomic-imaging parameters across the six longitudinal biological factor alterations (see Fig. 1D). We then evaluated the across-population stability of these model parameters via their $99 \%$ confidence intervals $(99 \% \mathrm{Cl})$. Next, rate of change of cognitive scores were calculated for each subject $(7.2 \pm 2.6$ time points for $\mathrm{HC}$ and 6.3 \pm 3.0 time points for AD). We applied singular value decomposition (SVD) multivariate analysis to evaluate how the stable transcriptomic-imaging interactions mediate group-specific changes in cognitive/clinical scores (age-related slopes of MMSE, ADAS-11, ADAS-13, EM, and EF). For each group (i.e. HC or AD), SVD identified a few pairs of "principal components" that maximize the cross-correlation between the two sets of variables (Carbonell et al., 2020; Worsley et al., 2005). Then it mapped the gene-imaging parameters onto the obtained principal components (PC). This mapping provides a score (or contribution) of a gene-imaging parameter to a PC. Next, the significant PC were identified by running 10000 permutations. To identify the genes (gene-imaging parameters) with large and reliable contributions on the significant PC, we drew 10000 bootstrap samples and calculated the bootstrap ratio 
medRxiv preprint doi: https://doi.org/10.1101/2021.02.23.21252283; this version posted March 1, 2021. The copyright holder for this preprint (which was not certified by peer review) is the author/funder, who has granted medRxiv a license to display the preprint in perpetuity.

It is made available under a CC-BY-NC-ND 4.0 International license.

of the gene-imaging parameters. The bootstrap ratio is obtained by dividing the geneimaging saliences (contributions) by their respective bootstrap standard errors. It allowed us to assess the reliability of the genetic contributions (Mclntosh et al., 2004). Hence, top aging- or AD-related causal genes were identified by selecting the parameters with bootstrap ratio above 2.58 , which is approximately equivalent to a zscore for $99 \% \mathrm{Cl}$ if the bootstrap distribution is normal (Efron et al., 1986) .

\section{Competing Interests}

There is no conflict of interest to declare with respect to this work.

\section{Author Contributions}

YIM and QA conceived the study and preprocessed the data. QA implemented the model and analyzed the data. FC assisted with the SVD multivariate statistical analysis. All authors contributed to the interpretation of the results. QA wrote the manuscript draft, with input from YIM, and prepared the figures/tables. All authors provided critical feedback and helped shape the research, analysis and manuscript.

\section{Code Availability}

We anticipate that the GE-MCM will be released soon as part of an already available open-access user-friendly multi-tool software for researchers (Yasser Iturria-Medina et al., 2020) at https://www.neuropm-lab.com/neuropm-box.html. Importantly, standalone applications for Linux, macOS and Windows systems are provided (MATLAB license and/or programming expertise are not required).

\section{Data availability}

All data used in this study are available at the Alzheimer's Disease Neuroimaging Initiative (ADNI) database (adni.loni.usc.edu) and the Allen Human Brain Atlas website (www.brain-map.org). 
medRxiv preprint doi: https://doi.org/10.1101/2021.02.23.21252283; this version posted March 1, 2021. The copyright holder for this preprint (which was not certified by peer review) is the author/funder, who has granted medRxiv a license to display the preprint in perpetuity.

\section{Acknowledgement}

This research was undertaken thanks in part to funding from: the Canada First Research Excellence Fund, awarded to McGill University for the Healthy Brains for Healthy Lives Initiative, the Fonds de la Recherche en Sante du Quebec (FRQS) Research Scholars Junior 1, the Canada Research Chair Tier-2 and the Weston Brain Institute Rapid Response programs 2018 and 2019 awards to YIM, and the Brain Canada Foundation and Health Canada support to the McConnell Brain Imaging Centre at the Montreal Neurological Institute. Dataset-1 collection and sharing was provided by Allen Institute for Brain Science (funded in part by the Department of Health and Human Services Health Resources and Services Administration award numbers 1C76HF15069-01-00 and 1C76HF19619-01- 00. The Allen Human Brain Atlas is also supported by Paul G. Allen Mr. and Mrs. Richard Daly, Mr. and Mrs. Peter Eschenbach, Mr. William E. Fay, Jr., Mr. Nathan Hansen, Mr. and Mrs. Richard Jernstedt, Bruce and Kathryn Johnson, Mr. and Mrs. Martin Koldyke, Michael and Suzanne Moskow, Bruce and Gwill Newman, Mr. and Mrs. Peter Pond, Mr. and Mrs. James N. Bayer, Jr., Mr. and Mrs. Richard L. Joutras, Mr. and Mrs. Robert Lorch, Lee and Jeanne Zehrer, and the Board Members of Brain Research Foundation.

The Dataset-2 collection and sharing for this project was funded by ADNI (National Institutes of Health Grant U01 AG024904) and DOD ADNI (Department of Defense award number W81XWH-12-2-0012). ADNI is funded by the National Institute on Aging, the National Institute of Biomedical Imaging and Bioengineering, and through generous contributions from the following: AbbVie, Alzheimer's Association; Alzheimer's Drug Discovery Foundation; Araclon Biotech; BioClinica, Inc.; Biogen; Bristol-Myers Squibb Company; CereSpir, Inc.; Eisai Inc.; Elan Pharmaceuticals, Inc.; Eli Lilly and Company; Eurolmmun; F. Hoffmann-La Roche Ltd and its affiliated company Genentech, Inc.; Fujirebio; GE Healthcare; IXICO Ltd.; Janssen Alzheimer Immunotherapy Research \& Development, LLC.; Johnson \& Johnson Pharmaceutical Research \& Development LLC.; Lumosity; Lundbeck; Merck \& Co., Inc.; Meso Scale Diagnostics, LLC.; NeuroRx Research; Neurotrack Technologies; Novartis Pharmaceuticals Corporation; Pfizer Inc.; Piramal Imaging; Servier; Takeda Pharmaceutical Company; and Transition Therapeutics. The Canadian Institutes of Health Research is providing funds to support ADNI clinical sites in Canada. Private sector contributions are facilitated by the Foundation for the National Institutes of 
medRxiv preprint doi: https://doi.org/10.1101/2021.02.23.21252283; this version posted March 1, 2021. The copyright holder for this preprint (which was not certified by peer review) is the author/funder, who has granted medRxiv a license to display the preprint in perpetuity. It is made available under a CC-BY-NC-ND 4.0 International license .

Health (www.fnih.org). The grantee organization is the Northern California Institute for Research and Education, and the study is coordinated by the Alzheimer's Disease Cooperative Study at the University of California, San Diego. ADNI data are disseminated by the Laboratory for Neuro Imaging at the University of Southern California. 
medRxiv preprint doi: https://doi.org/10.1101/2021.02.23.21252283; this version posted March 1, 2021. The copyright holder for this preprint (which was not certified by peer review) is the author/funder, who has granted medRxiv a license to display the preprint in perpetuity.

\section{References}

Alkadhi, K., \& Eriksen, J. (2011). The complex and multifactorial nature of Alzheimer's disease. Current neuropharmacology, 9(4), 586-586. doi:10.2174/157015911798376235

Allen Human Brain Atlas. (2013). Technical white paper: In situ hybridization in the Allen Human Brain Atlas. http://help.brainmap.org/download/attachments/2818165/ISH WhitePaper.pdf?version=1\&modificati onDate $=1382051868332 \& a p i=v 2$

Anderson, C. M., Hu, J., Barnes, R. M., Heidt, A. B., Cornelissen, I., \& Black, B. L. (2015). Myocyte enhancer factor $2 \mathrm{C}$ function in skeletal muscle is required for normal growth and glucose metabolism in mice. Skeletal muscle, 5, 7-7. doi:10.1186/s13395-015$0031-0$

Ashburner, J. (2007). A fast diffeomorphic image registration algorithm. Neuroimage, 38(1), 95-113. doi:10.1016/j.neuroimage.2007.07.007

Austin, S. A., Santhanam, A. V., \& Katusic, Z. S. (2010). Endothelial nitric oxide modulates expression and processing of amyloid precursor protein. Circulation research, 107(12), 1498-1502. doi:10.1161/CIRCRESAHA.110.233080

Bezzi, P., Domercq, M., Brambilla, L., Galli, R., Schols, D., De Clercq, E., . . Volterra, A. (2001). CXCR4-activated astrocyte glutamate release via TNFa: amplification by microglia triggers neurotoxicity. Nature Neuroscience, 4(7), 702-710. doi:10.1038/89490

Bhattacharya, A., Chakraborty, A., \& Mallick, B. K. (2016). Fast sampling with Gaussian scalemixture priors in high-dimensional regression. Biometrika, 103(4), 985-991. doi:10.1093/biomet/asw042

Budanov, A. V., Lee, J. H., \& Karin, M. (2010). Stressin' Sestrins take an aging fight. EMBO Mol Med, 2(10), 388-400. doi:10.1002/emmm.201000097

Carbonell, F., Zijdenbos, A. P., \& Bedell, B. J. (2020). Spatially Distributed Amyloid- $\beta$ Reduces Glucose Metabolism in Mild Cognitive Impairment. J Alzheimers Dis, 73(2), 543-557. doi:10.3233/jad-190560

Carvalho, C. M., Polson, N. G., \& Scott, J. G. (2010). The horseshoe estimator for sparse signals. Biometrika, 97(2), 465-480.

Chanprasertyothin, S., Jongjaroenprasert, W., \& Ongphiphadhanakul, B. (2015). The association of soluble IGF2R and IGF2R gene polymorphism with type 2 diabetes. Journal of diabetes research, 2015, 216383-216383. doi:10.1155/2015/216383

Chao-Gan, Y., \& Yu-Feng, Z. (2010). DPARSF: A MATLAB Toolbox for "Pipeline" Data Analysis of Resting-State fMRI. Front Syst Neurosci, 4, 13. doi:10.3389/fnsys.2010.00013

Chen, C. Y., Tsai, H. Y., Tsai, S. H., Chu, P. H., Huang, P. H., Chen, J. W., \& Lin, S. J. (2020). Deletion of the FHL2 gene attenuates intima-media thickening in a partially ligated carotid artery ligated mouse model. J Cell Mol Med, 24(1), 160-173. doi: $10.1111 / \mathrm{jcmm} .14687$

Chen, S.-D., Yang, J.-L., Lin, T.-K., \& Yang, D.-I. (2019). Emerging Roles of Sestrins in Neurodegenerative Diseases: Counteracting Oxidative Stress and Beyond. Journal of clinical medicine, 8(7), 1001. doi:10.3390/jcm8071001 
medRxiv preprint doi: https://doi.org/10.1101/2021.02.23.21252283; this version posted March 1, 2021. The copyright holder for this preprint (which was not certified by peer review) is the author/funder, who has granted medRxiv a license to display the preprint in perpetuity.

Chong, Y., Saviuk, N., Pie, B., Basisty, N., Quinn, R. K., Schilling, B., . . Haghighi, A. P. (2018). Removing 4E-BP Enables Synapses to Refine without Postsynaptic Activity. Cell Rep, 23(1), 11-22. doi:10.1016/j.celrep.2018.03.040

Chu, P. H., Yeh, L. K., Lin, H. C., Jung, S. M., Ma, D. H., Wang, I. J., . . Chen, J. (2008). Deletion of the FHL2 gene attenuating neovascularization after corneal injury. Invest Ophthalmol Vis Sci, 49(12), 5314-5318. doi:10.1167/iovs.08-2209

Cui, Y., Huang, L., Elefteriou, F., Yang, G., Shelton, J. M., Giles, J. E., . . . Li, C. (2004). Essential role of STAT3 in body weight and glucose homeostasis. Molecular and cellular biology, 24(1), 258-269. doi:10.1128/mcb.24.1.258-269.2004

D'Amelio, M., Cavallucci, V., \& Cecconi, F. (2010). Neuronal caspase-3 signaling: not only cell death. Cell Death \& Differentiation, 17(7), 1104-1114. doi:10.1038/cdd.2009.180

de Oliveira, P. G., Ramos, M. L. S., Amaro, A. J., Dias, R. A., \& Vieira, S. I. (2019). G(i/o)Protein Coupled Receptors in the Aging Brain. Frontiers in aging neuroscience, 11, 8989. doi:10.3389/fnagi.2019.00089

DeTure, M. A., \& Dickson, D. W. (2019). The neuropathological diagnosis of Alzheimer's disease. Molecular neurodegeneration, 14(1), 32. doi:10.1186/s13024-019-0333-5

Dillman, A. A., Majounie, E., Ding, J., Gibbs, J. R., Hernandez, D., Arepalli, S., . . Cookson, M. R. (2017). Transcriptomic profiling of the human brain reveals that altered synaptic gene expression is associated with chronological aging. Sci Rep, 7(1), 16890. doi:10.1038/s41598-017-17322-0

Dreyer, J., Schleicher, M., Tappe, A., Schilling, K., Kuner, T., Kusumawidijaja, G., . . Kuner, R. (2004). Nitric oxide synthase (NOS)-interacting protein interacts with neuronal NOS and regulates its distribution and activity. J Neurosci, 24(46), 10454-10465. doi:10.1523/jneurosci.2265-04.2004

Dukart, J., Kherif, F., Mueller, K., Adaszewski, S., Schroeter, M. L., Frackowiak, R. S. J., . . . Alzheimer's Disease Neuroimaging, I. (2013). Generative FDG-PET and MRI model of aging and disease progression in Alzheimer's disease. PLoS computational biology, 9(4), e1002987-e1002987. doi:10.1371/journal.pcbi.1002987

Efron, B., \& Tibshirani, R. (1986). Bootstrap Methods for Standard Errors, Confidence Intervals, and Other Measures of Statistical Accuracy. Statist. Sci., 1(1), 54-75. doi:10.1214/ss/1177013815

Evans, A. C., Kamber, M., Collins, D. L., \& MacDonald, D. (1994). An MRI-Based Probabilistic Atlas of Neuroanatomy. In S. D. Shorvon, D. R. Fish, F. Andermann, G. M. Bydder, \& H. Stefan (Eds.), Magnetic Resonance Scanning and Epilepsy (pp. 263-274). Boston, MA: Springer US.

Folch-Fortuny, A., Arteaga, F., \& Ferrer, A. (2016). Missing Data Imputation Toolbox for MATLAB. Chemometrics and Intelligent Laboratory Systems, 154, 93-100. doi:https://doi.org/10.1016/i.chemolab.2016.03.019

Freeze, B., Acosta, D., Pandya, S., Zhao, Y., \& Raj, A. (2018). Regional expression of genes mediating trans-synaptic alpha-synuclein transfer predicts regional atrophy in Parkinson disease. Neuroimage Clin, 18, 456-466. doi:10.1016/j.nicl.2018.01.009

Freeze, B., Pandya, S., Zeighami, Y., \& Raj, A. (2019). Regional transcriptional architecture of Parkinson's disease pathogenesis and network spread. Brain, 142(10), 3072-3085. doi:10.1093/brain/awz223 
medRxiv preprint doi: https://doi.org/10.1101/2021.02.23.21252283; this version posted March 1, 2021. The copyright holder for this preprint (which was not certified by peer review) is the author/funder, who has granted medRxiv a license to display the preprint in perpetuity.

Ge, J., Chen, Q., Liu, B., Wang, L., Zhang, S., \& Ji, B. (2017). Knockdown of Rab21 inhibits proliferation and induces apoptosis in human glioma cells. Cell Mol Biol Lett, 22, 30. doi:10.1186/s11658-017-0062-0

Gibbons, L. E., Carle, A. C., Mackin, R. S., Harvey, D., Mukherjee, S., Insel, P., . . Alzheimer's Disease Neuroimaging, I. (2012). A composite score for executive functioning, validated in Alzheimer's Disease Neuroimaging Initiative (ADNI) participants with baseline mild cognitive impairment. Brain Imaging Behav, 6(4), 517-527. doi:10.1007/s11682-012-9176-1

Giustiniani, J., Guillemeau, K., Dounane, O., Sardin, E., Huvent, I., Schmitt, A., . . . Chambraud, B. (2015). The FK506-binding protein FKBP52 in vitro induces aggregation of truncated Tau forms with prion-like behavior. Faseb j, 29(8), 3171-3181. doi:10.1096/fj.14-268243

Giustiniani, J., Sineus, M., Sardin, E., Dounane, O., Panchal, M., Sazdovitch, V., .. . Baulieu, E. E. (2012). Decrease of the immunophilin FKBP52 accumulation in human brains of Alzheimer's disease and FTDP-17. J Alzheimers Dis, 29(2), 471-483. doi:10.3233/jad2011-111895

Gryglewski, G., Seiger, R., James, G. M., Godbersen, G. M., Komorowski, A., Unterholzner, J., . . Lanzenberger, R. (2018). Spatial analysis and high resolution mapping of the human whole-brain transcriptome for integrative analysis in neuroimaging. Neuroimage, 176, 259-267. doi:10.1016/j.neuroimage.2018.04.068

Guerreiro, R., \& Bras, J. (2015). The age factor in Alzheimer's disease. Genome medicine, 7, 106-106. doi:10.1186/s13073-015-0232-5

Hawrylycz, M. J., Lein, E. S., Guillozet-Bongaarts, A. L., Shen, E. H., Ng, L., Miller, J. A., . . Jones, A. R. (2012). An anatomically comprehensive atlas of the adult human brain transcriptome. Nature, 489(7416), 391-399. doi:10.1038/nature11405

Homolak, J., Mudrovčić, M., Vukić, B., \& Toljan, K. (2018). Circadian Rhythm and Alzheimer's Disease. Medical sciences (Basel, Switzerland), 6(3), 52. doi:10.3390/medsci6030052

laccarino, L., Tammewar, G., Ayakta, N., Baker, S. L., Bejanin, A., Boxer, A. L., . . Rabinovici, G. D. (2017). Local and distant relationships between amyloid, tau and neurodegeneration in Alzheimer's Disease. Neurolmage. Clinical, 17, 452-464. doi:10.1016/j.nicl.2017.09.016

Inoue, H., Ogawa, W., Ozaki, M., Haga, S., Matsumoto, M., Furukawa, K., . . Kasuga, M. (2004). Role of STAT-3 in regulation of hepatic gluconeogenic genes and carbohydrate metabolism in vivo. Nature Medicine, 10(2), 168-174. doi:10.1038/nm980

Ittner, L. M., \& Götz, J. (2011). Amyloid- $\beta$ and tau--a toxic pas de deux in Alzheimer's disease. Nat Rev Neurosci, 12(2), 65-72. doi:10.1038/nrn2967

Iturria-Medina, Y., Carbonell, F., Assadi, A., Adewale, Q., Khan, A. F., Baumeister, R., \& Sanchez-Rodriguez, L. M. (2020). NeuroPM toolbox: integrating Molecular, Neuroimaging and Clinical data for Characterizing Neuropathological Progression and Individual Therapeutic Needs. medRxiv, 2020.2009.2024.20200964. doi:10.1101/2020.09.24.20200964

Iturria-Medina, Y., Carbonell, F. M., \& Evans, A. C. (2018). Multimodal imaging-based therapeutic fingerprints for optimizing personalized interventions: Application to neurodegeneration. Neuroimage, 179, 40-50. doi:10.1016/j.neuroimage.2018.06.028 
medRxiv preprint doi: https://doi.org/10.1101/2021.02.23.21252283; this version posted March 1, 2021. The copyright holder for this preprint (which was not certified by peer review) is the author/funder, who has granted medRxiv a license to display the preprint in perpetuity.

Iturria-Medina, Y., Carbonell, F. M., Sotero, R. C., Chouinard-Decorte, F., Evans, A. C., \& Alzheimer's Disease Neuroimaging, I. (2017). Multifactorial causal model of brain (dis)organization and therapeutic intervention: Application to Alzheimer's disease. Neuroimage, 152, 60-77. doi:10.1016/j.neuroimage.2017.02.058

Iturria-Medina, Y., Khan, A. F., Adewale, Q., Shirazi, A. H., \& Alzheimer's Disease Neuroimaging, I. (2020). Blood and brain gene expression trajectories mirror neuropathology and clinical deterioration in neurodegeneration. Brain, 143(2), 661673. doi:10.1093/brain/awz400

Iturria-Medina, Y., Sotero, R. C., Toussaint, P. J., Mateos-Perez, J. M., Evans, A. C., \& Alzheimer's Disease Neuroimaging, I. (2016). Early role of vascular dysregulation on late-onset Alzheimer's disease based on multifactorial data-driven analysis. Nat Commun, 7, 11934. doi:10.1038/ncomms11934

Jack, C. R., Jr., Wiste, H. J., Schwarz, C. G., Lowe, V. J., Senjem, M. L., Vemuri, P., . . . Petersen, R. C. (2018). Longitudinal tau PET in ageing and Alzheimer's disease. Brain, 141(5), 1517-1528. doi:10.1093/brain/awy059

Jagust, W. J., Bandy, D., Chen, K., Foster, N. L., Landau, S. M., Mathis, C. A., . . Alzheimer's Disease Neuroimaging, I. (2010). The Alzheimer's Disease Neuroimaging Initiative positron emission tomography core. Alzheimers Dement, 6(3), 221-229. doi:10.1016/j.jalz.2010.03.003

Jasinska, A. J., Service, S., Choi, O. W., DeYoung, J., Grujic, O., Kong, S. Y., . . Freimer, N. B. (2009). Identification of brain transcriptional variation reproduced in peripheral blood: an approach for mapping brain expression traits. Hum Mol Genet, 18(22), 44154427. doi:10.1093/hmg/ddp397

Johnson, E. C. B., Dammer, E. B., Duong, D. M., Ping, L., Zhou, M., Yin, L., . . Seyfried, N. T. (2020). Large-scale proteomic analysis of Alzheimer's disease brain and cerebrospinal fluid reveals early changes in energy metabolism associated with microglia and astrocyte activation. Nat Med, 26(5), 769-780. doi:10.1038/s41591-0200815-6

Johnson, E. C. B., Dammer, E. B., Duong, D. M., Yin, L., Thambisetty, M., Troncoso, J. C., . . . Seyfried, N. T. (2018). Deep proteomic network analysis of Alzheimer's disease brain reveals alterations in RNA binding proteins and RNA splicing associated with disease. Molecular neurodegeneration, 13(1), 52-52. doi:10.1186/s13024-018-0282-4

Khan, M. Z., Brandimarti, R., Shimizu, S., Nicolai, J., Crowe, E., \& Meucci, O. (2008). The chemokine CXCL12 promotes survival of postmitotic neurons by regulating Rb protein. Cell death and differentiation, 15(10), 1663-1672. doi:10.1038/cdd.2008.95

Kim, M., Sujkowski, A., Namkoong, S., Gu, B., Cobb, T., Kim, B., . . Lee, J. H. (2020). Sestrins are evolutionarily conserved mediators of exercise benefits. Nature Communications, 11(1), 190. doi:10.1038/s41467-019-13442-5

Kim, Y. N., Jung, H. Y., Eum, W. S., Kim, D. W., Shin, M. J., Ahn, E. H., . . Choi, S. Y. (2014). Neuroprotective effects of PEP-1-carbonyl reductase 1 against oxidative-stressinduced ischemic neuronal cell damage. Free Radic Biol Med, 69, 181-196. doi:10.1016/j.freeradbiomed.2014.01.006

Klein, A., \& Tourville, J. (2012). 101 labeled brain images and a consistent human cortical labeling protocol. Front Neurosci, 6, 171. doi:10.3389/fnins.2012.00171

Koch, L. (2018). Altered splicing in Alzheimer transcriptomes. Nature Reviews Genetics, 19(12), 738-739. doi:10.1038/s41576-018-0064-4 
medRxiv preprint doi: https://doi.org/10.1101/2021.02.23.21252283; this version posted March 1, 2021. The copyright holder for this preprint (which was not certified by peer review) is the author/funder, who has granted medRxiv a license to display the preprint in perpetuity.

Kowald, A., \& Kirkwood, T. B. (1996). A network theory of ageing: the interactions of defective mitochondria, aberrant proteins, free radicals and scavengers in the ageing process. Mutat Res, 316(5-6), 209-236. doi:10.1016/s0921-8734(96)90005-3

Kuintzle, R. C., Chow, E. S., Westby, T. N., Gvakharia, B. O., Giebultowicz, J. M., \& Hendrix, D. A. (2017). Circadian deep sequencing reveals stress-response genes that adopt robust rhythmic expression during aging. Nature Communications, 8, 14529-14529. doi:10.1038/ncomms 14529

Kurien, P., Hsu, P. K., Leon, J., Wu, D., McMahon, T., Shi, G., . . Ptáček, L. J. (2019). TIMELESS mutation alters phase responsiveness and causes advanced sleep phase. Proc Natl Acad Sci U S A, 116(24), 12045-12053. doi:10.1073/pnas.1819110116

Lee, T. I., \& Young, R. A. (2013). Transcriptional regulation and its misregulation in disease. Cell, 152(6), 1237-1251. doi:10.1016/j.cell.2013.02.014

Li, L., Xiao, L., Hou, Y., He, Q., Zhu, J., Li, Y., . . . Zhao, Y. (2016). Sestrin2 Silencing Exacerbates Cerebral Ischemia/Reperfusion Injury by Decreasing Mitochondrial Biogenesis through the AMPK/PGC-1a Pathway in Rats. Sci Rep, 6, 30272. doi:10.1038/srep30272

Liang, B., Duan, B. Y., Zhou, X. P., Gong, J. X., \& Luo, Z. G. (2010). Calpain activation promotes BACE1 expression, amyloid precursor protein processing, and amyloid plaque formation in a transgenic mouse model of Alzheimer disease. J Biol Chem, 285(36), 27737-27744. doi:10.1074/jbc.M110.117960

Makalic, E., \& Schmidt, D. F. (2016). A simple sampler for the horseshoe estimator. IEEE Signal Processing Letters, 23(1), 179-182. doi:10.1109/LSP.2015.2503725

McIntosh, A. R., \& Lobaugh, N. J. (2004). Partial least squares analysis of neuroimaging data: applications and advances. Neuroimage, 23 Suppl 1, S250-263. doi:10.1016/j.neuroimage.2004.07.020

Mei, Z., Yan, P., Tan, X., Zheng, S., \& Situ, B. (2015). Transcriptional Regulation of BACE1 by NFAT3 Leads to Enhanced Amyloidogenic Processing. Neurochemical Research, 40(4), 829-836. doi:10.1007/s11064-015-1533-1

Mello, T., Materozzi, M., Zanieri, F., Simeone, I., Ceni, E., Bereshchenko, O., . . Galli, A. (2020). Liver haploinsufficiency of RuvBL1 causes hepatic insulin resistance and enhances hepatocellular carcinoma progression. Int J Cancer, 146(12), 3410-3422. doi:10.1002/ijc.32787

Mi, H., Muruganujan, A., Casagrande, J. T., \& Thomas, P. D. (2013). Large-scale gene function analysis with the PANTHER classification system. Nature protocols, 8(8), 1551-1566. doi:10.1038/nprot.2013.092

Morales-Corraliza, J., Berger, J. D., Mazzella, M. J., Veeranna, Neubert, T. A., Ghiso, J., . . . Mathews, P. M. (2012). Calpastatin modulates APP processing in the brains of $\beta$ amyloid depositing but not wild-type mice. Neurobiology of aging, 33(6), 1125.e11291125.e1121.1125E1118. doi:10.1016/j.neurobiolaging.2011.11.023

Mostafavi, S., Gaiteri, C., Sullivan, S. E., White, C. C., Tasaki, S., Xu, J., . . De Jager, P. L. (2018). A molecular network of the aging human brain provides insights into the pathology and cognitive decline of Alzheimer's disease. Nature Neuroscience, 21(6), 811-819. doi:10.1038/s41593-018-0154-9

Niccoli, T., \& Partridge, L. (2012). Ageing as a risk factor for disease. Current biology : $C B$, 22(17), 741-752. doi:10.1016/j.cub.2012.07.024 
medRxiv preprint doi: https://doi.org/10.1101/2021.02.23.21252283; this version posted March 1, 2021. The copyright holder for this preprint (which was not certified by peer review) is the author/funder, who has granted medRxiv a license to display the preprint in perpetuity.

Palomero-Gallagher, N., \& Zilles, K. (2019). Cortical layers: Cyto-, myelo-, receptor- and synaptic architecture in human cortical areas. Neuroimage, 197, 716-741. doi:10.1016/j.neuroimage.2017.08.035

Pascoal, T. A., Mathotaarachchi, S., Mohades, S., Benedet, A. L., Chung, C. O., Shin, M., . . - Rosa-Neto, P. (2017). Amyloid- $\beta$ and hyperphosphorylated tau synergy drives metabolic decline in preclinical Alzheimer's disease. Molecular Psychiatry, 22(2), 306311. doi:10.1038/mp.2016.37

Pickett, E. K., Herrmann, A. G., McQueen, J., Abt, K., Dando, O., Tulloch, J., . . Spires-Jones, T. L. (2019). Amyloid Beta and Tau Cooperate to Cause Reversible Behavioral and Transcriptional Deficits in a Model of Alzheimer's Disease. Cell Rep, 29(11), 35923604.e3595. doi:10.1016/j.celrep.2019.11.044

Prudente, S., Sesti, G., Pandolfi, A., Andreozzi, F., Consoli, A., \& Trischitta, V. (2012). The mammalian tribbles homolog TRIB3, glucose homeostasis, and cardiovascular diseases. Endocrine reviews, 33(4), 526-546. doi:10.1210/er.2011-1042

Qosa, H., Abuasal, B. S., Romero, I. A., Weksler, B., Couraud, P. O., Keller, J. N., \& Kaddoumi, A. (2014). Differences in amyloid- $\beta$ clearance across mouse and human blood-brain barrier models: kinetic analysis and mechanistic modeling. Neuropharmacology, 79, 668-678. doi:10.1016/j.neuropharm.2014.01.023

Rochette, L., Lorin, J., Zeller, M., Guilland, J. C., Lorgis, L., Cottin, Y., \& Vergely, C. (2013). Nitric oxide synthase inhibition and oxidative stress in cardiovascular diseases: possible therapeutic targets? Pharmacol Ther, 140(3), 239-257. doi:10.1016/j.pharmthera.2013.07.004

Rodrigue, K. M., Kennedy, K. M., Devous, M. D., Sr., Rieck, J. R., Hebrank, A. C., DiazArrastia, R., . . . Park, D. C. (2012). $\beta$-Amyloid burden in healthy aging: regional distribution and cognitive consequences. Neurology, 78(6), 387-395. doi:10.1212/WNL.0b013e318245d295

Rodríguez-Rodero, S., Fernández-Morera, J. L., Menéndez-Torre, E., Calvanese, V., Fernández, A. F., \& Fraga, M. F. (2011). Aging genetics and aging. Aging and disease, 2(3), 186-195. Retrieved from https://pubmed.ncbi.nlm.nih.gov/22396873

https://www.ncbi.nlm.nih.gov/pmc/articles/PMC3295054/

Sahu, S. K., Gummadi, S. N., Manoj, N., \& Aradhyam, G. K. (2007). Phospholipid scramblases: An overview. Archives of Biochemistry and Biophysics, 462(1), 103-114. doi:https://doi.org/10.1016/j.abb.2007.04.002

Sao, T., Yoshino, Y., Yamazaki, K., Ozaki, Y., Mori, Y., Ochi, S., . . Ueno, S. I. (2018). MEF2C mRNA expression and cognitive function in Japanese patients with Alzheimer's disease. Psychiatry Clin Neurosci, 72(3), 160-167. doi:10.1111/pcn.12618

Shi, X., Xu, L., Malagult, J., Tang, J., Yan, M., \& Zhang, J. H. (2017). Sestrins: A New Kid for Stroke Treatment? Curr Drug Deliv, 14(6), 797-806. doi:10.2174/1567201814666161111125249

Singh, P. P., Demmitt, B. A., Nath, R. D., \& Brunet, A. (2019). The Genetics of Aging: A Vertebrate Perspective. Cell, 177(1), 200-220. doi:10.1016/j.cell.2019.02.038

Sled, J. G., Zijdenbos, A. P., \& Evans, A. C. (1998). A nonparametric method for automatic correction of intensity nonuniformity in MRI data. IEEE Trans Med Imaging, 17(1), 8797. doi:10.1109/42.668698 
medRxiv preprint doi: https://doi.org/10.1101/2021.02.23.21252283; this version posted March 1, 2021. The copyright holder for this preprint (which was not certified by peer review) is the author/funder, who has granted medRxiv a license to display the preprint in perpetuity.

Su, L.-N., Song, X.-Q., Xue, Z.-X., Zheng, C.-Q., Yin, H.-F., \& Wei, H.-P. (2018). Network analysis of microRNAs, transcription factors, and target genes involved in axon regeneration. Journal of Zhejiang University. Science. B, 19(4), 293-304. doi:10.1631/jzus.B1700179

Subramanian, A., Narayan, R., Corsello, S. M., Peck, D. D., Natoli, T. E., Lu, X., ... Golub, T. R. (2017). A Next Generation Connectivity Map: L1000 Platform and the First 1,000,000 Profiles. Cell, 171(6), 1437-1452.e1417. doi:10.1016/j.cell.2017.10.049

Sullivan, P. F., Fan, C., \& Perou, C. M. (2006). Evaluating the comparability of gene expression in blood and brain. Am J Med Genet B Neuropsychiatr Genet, 141b(3), 261-268. doi:10.1002/ajmg.b.30272

Tanaka, T., Biancotto, A., Moaddel, R., Moore, A. Z., Gonzalez-Freire, M., Aon, M. A., . . . Ferrucci, L. (2018). Plasma proteomic signature of age in healthy humans. Aging cell, 17(5), e12799-e12799. doi:10.1111/acel.12799

Taneera, J., Dhaiban, S., Mohammed, A. K., Mukhopadhyay, D., Aljaibeji, H., Sulaiman, N., . .. Salehi, A. (2019). GNAS gene is an important regulator of insulin secretory capacity in pancreatic $\quad \beta$-cells. $\quad$ Gene, 715, 144028. doi:https://doi.org/10.1016/i.gene.2019.144028

Thathiah, A., \& De Strooper, B. (2011). The role of G protein-coupled receptors in the pathology of Alzheimer's disease. Nature Reviews Neuroscience, 12(2), 73-87. doi:10.1038/nrn2977

Toepper, M. (2017). Dissociating Normal Aging from Alzheimer's Disease: A View from Cognitive Neuroscience. Journal of Alzheimer's disease : JAD, 57(2), 331-352. doi:10.3233/JAD-161099

Twine, N. A., Janitz, K., Wilkins, M. R., \& Janitz, M. (2011). Whole transcriptome sequencing reveals gene expression and splicing differences in brain regions affected by Alzheimer's disease. PLoS One, 6(1), e16266. doi:10.1371/journal.pone.0016266

Ubaida-Mohien, C., Lyashkov, A., Gonzalez-Freire, M., Tharakan, R., Shardell, M., Moaddel, R., ... Ferrucci, L. (2019). Discovery proteomics in aging human skeletal muscle finds change in spliceosome, immunity, proteostasis and mitochondria. Elife, 8. doi:10.7554/eLife.49874

Wang, C., Yue, H., Hu, Z., Shen, Y., Ma, J., Li, J., . . Gu, Y. (2020). Microglia mediate forgetting via complement-dependent synaptic elimination. Science, 367(6478), 688694. doi:10.1126/science.aaz2288

Witt, S. H., Sommer, W. H., Hansson, A. C., Sticht, C., Rietschel, M., \& Witt, C. C. (2013). Comparison of gene expression profiles in the blood, hippocampus and prefrontal cortex of rats. In Silico Pharmacology, 1(1), 15. doi:10.1186/2193-9616-1-15

Worsley, K. J., Chen, J.-I., Lerch, J., \& Evans, A. C. (2005). Comparing Functional Connectivity via Thresholding Correlations and Singular Value Decomposition. Philosophical Transactions: Biological Sciences, 360(1457), 913-920.

Xia, X., Jiang, Q., McDermott, J., \& Han, J.-D. J. (2018). Aging and Alzheimer's disease: Comparison and associations from molecular to system level. Aging cell, 17(5), e12802-e12802. doi:10.1111/acel.12802

Xu, Y., Liu, C., Chen, S., Ye, Y., Guo, M., Ren, Q., . . Chen, L. (2014). Activation of AMPK and inactivation of Akt result in suppression of mTOR-mediated S6K1 and 4E-BP1 
medRxiv preprint doi: https://doi.org/10.1101/2021.02.23.21252283; this version posted March 1, 2021. The copyright holder for this preprint (which was not certified by peer review) is the author/funder, who has granted medRxiv a license to display the preprint in perpetuity.

It is made available under a CC-BY-NC-ND 4.0 International license .

pathways leading to neuronal cell death in in vitro models of Parkinson's disease. Cellular Signalling, 26(8), 1680-1689. doi:https://doi.org/10.1016/i.cellsig.2014.04.009

Yang, Y. L., Loh, K. S., Liou, B. Y., Chu, I. H., Kuo, C. J., Chen, H. D., \& Chen, C. S. (2013). SESN-1 is a positive regulator of lifespan in Caenorhabditis elegans. Exp Gerontol, 48(3), 371-379. doi:10.1016/j.exger.2012.12.011

Ye, R., Gordillo, R., Shao, M., Onodera, T., Chen, Z., Chen, S., . . Scherer, P. E. (2018). Intracellular lipid metabolism impairs $\beta$ cell compensation during diet-induced obesity. The Journal of clinical investigation, 128(3), 1178-1189. doi:10.1172/JCI97702

Yeh, F. C., Liu, L., Hitchens, T. K., \& Wu, Y. L. (2017). Mapping immune cell infiltration using restricted diffusion MRI. Magn Reson Med, 77(2), 603-612. doi:10.1002/mrm.26143

Yeh, F. C., Panesar, S., Fernandes, D., Meola, A., Yoshino, M., Fernandez-Miranda, J. C., . . . Verstynen, T. (2018). Population-averaged atlas of the macroscale human structural connectome and its network topology. Neuroimage, 178, 57-68. doi:10.1016/j.neuroimage.2018.05.027

Yeh, F. C., \& Tseng, W. Y. (2011). NTU-90: a high angular resolution brain atlas constructed by q-space diffeomorphic reconstruction. Neuroimage, 58(1), 91-99. doi:10.1016/j.neuroimage.2011.06.021

Yeh, F. C., Verstynen, T. D., Wang, Y., Fernández-Miranda, J. C., \& Tseng, W. Y. (2013). Deterministic diffusion fiber tracking improved by quantitative anisotropy. PLoS One, 8(11), e80713. doi:10.1371/journal.pone.0080713

Yeh, F. C., Wedeen, V. J., \& Tseng, W. Y. (2010). Generalized q-sampling imaging. IEEE Trans Med Imaging, 29(9), 1626-1635. doi:10.1109/tmi.2010.2045126

Zhang, N., Gordon, M. L., \& Goldberg, T. E. (2017). Cerebral blood flow measured by arterial spin labeling MRI at resting state in normal aging and Alzheimer's disease. Neuroscience and biobehavioral reviews, 72, 168-175. doi:10.1016/j.neubiorev.2016.11.023

Zhang, W., Liu, J., Tian, L., Liu, Q., Fu, Y., \& Garvey, W. T. (2013). TRIB3 mediates glucoseinduced insulin resistance via a mechanism that requires the hexosamine biosynthetic pathway. Diabetes, 62(12), 4192-4200. doi:10.2337/db13-0312

Zhang, W., Wu, M., Kim, T., Jariwala, R. H., Garvey, W. J., Luo, N., . . Garvey, W. T. (2016). Skeletal Muscle TRIB3 Mediates Glucose Toxicity in Diabetes and High- Fat DietInduced Insulin Resistance. Diabetes, 65(8), 2380-2391. doi:10.2337/db16-0154

Zhao, Z., Ho, L., Suh, J., Qin, W., Pyo, H., Pompl, P., . . Pasinetti, G. M. (2003). A role of P301L tau mutant in anti-apoptotic gene expression, cell cycle and apoptosis. Mol Cell Neurosci, 24(2), 367-379. doi:10.1016/s1044-7431(03)00175-1

Zheng, Y. Q., Zhang, Y., Yau, Y., Zeighami, Y., Larcher, K., Misic, B., \& Dagher, A. (2019). Local vulnerability and global connectivity jointly shape neurodegenerative disease propagation. PLoS Biol, 17(11), e3000495. doi:10.1371/journal.pbio.3000495

Zlokovic, B. V. (2011). Neurovascular pathways to neurodegeneration in Alzheimer's disease and other disorders. Nature reviews. Neuroscience, 12(12), 723-738. doi:10.1038/nrn3114 


\section{SUPPLEMENTARY INFORMATION}

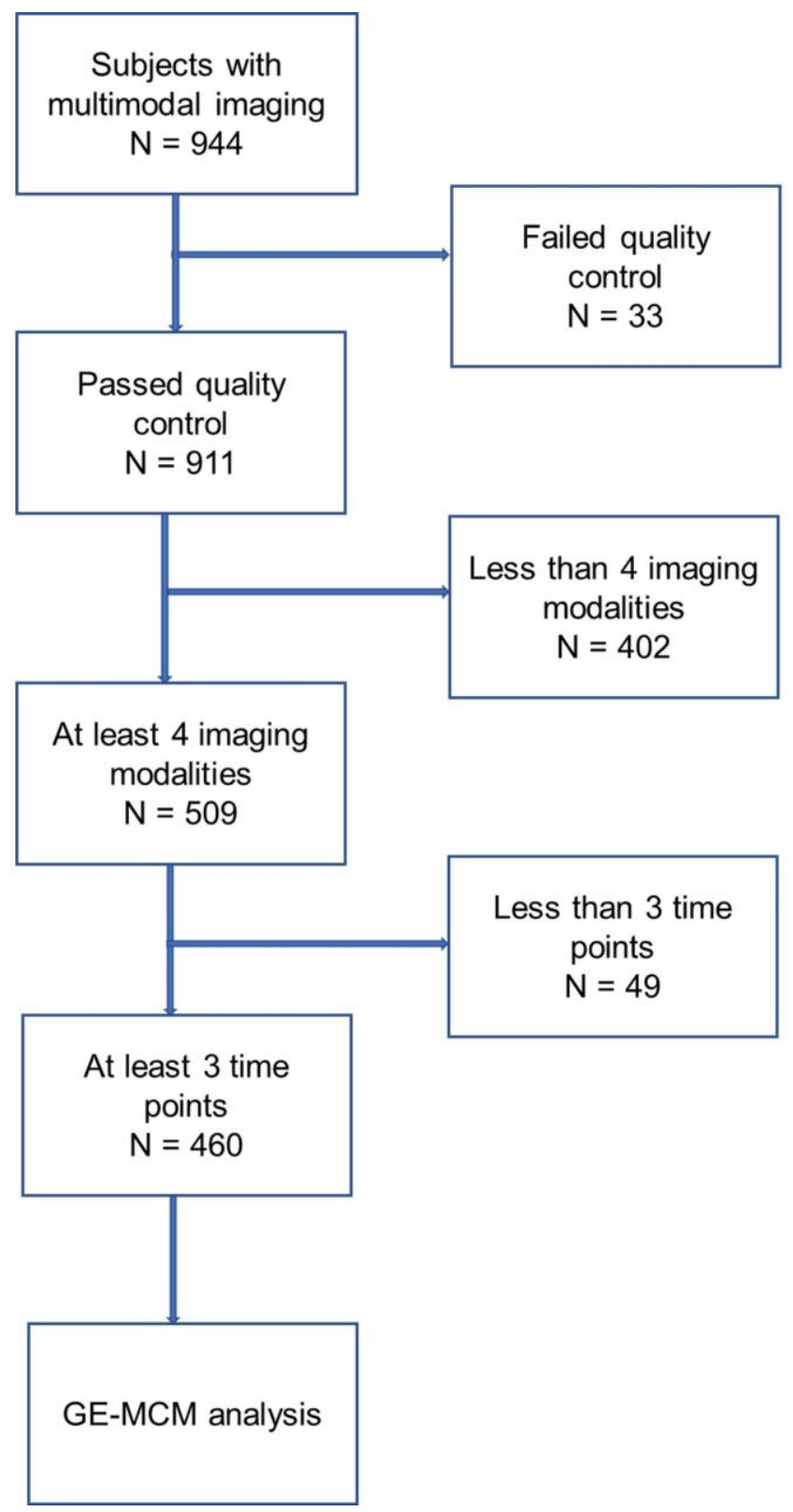

Figure 1-figure supplement 1: Subject selection. A multivariate outlier identification was performed based on 944 subjects. From the 911 subjects that survived outlier detection, 509 subjects having at least four imaging modalities were chosen. Then, 460 subjects with at least three time points in any of the imaging modalities were selected. Next, for each of the 460 subjects, missing imaging modalities at each time point having actual individual data were automatically imputed using the trimmed scores regression with internal PCA. 


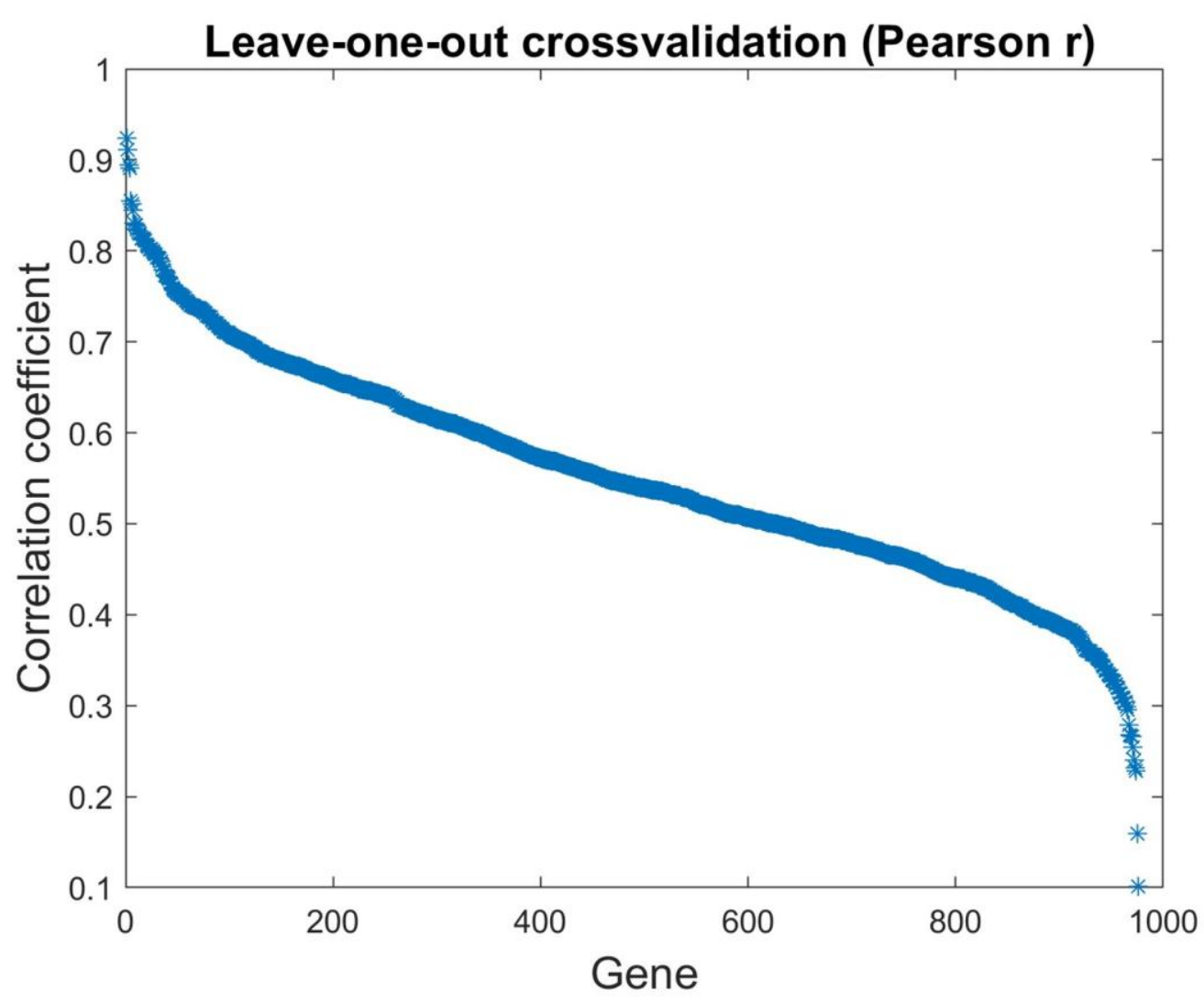

Figure 1-figure supplement 2: Correlation of predicted mRNA expression with actual mRNA expression across 976 genes. Using the actual mRNA values of 3702 samples from AHBA, Gaussian kernel regression was used to reproduce the mRNA intensities through a leave-one-out cross-validation, and the Pearson correlation coefficient between the actual and reproduced values was calculated for each gene.

Supplementary File 1: Main demographic characteristics of the included ADNI subjects.

\begin{tabular}{|c|c|c|c|c|c|c|}
\hline Variable & $\begin{array}{c}\text { HC } \\
(\mathbf{N}=151)\end{array}$ & $\begin{array}{c}\mathbf{E M C l} \\
(\mathbf{N}=161)\end{array}$ & $\begin{array}{c}\text { LMCI } \\
(\mathbf{N}=113)\end{array}$ & $\begin{array}{c}\text { AD } \\
(\mathbf{N}=35)\end{array}$ & $\begin{array}{c}\text { Stable } \\
\mathbf{H C} \\
(\mathbf{N}=113)\end{array}$ & $\begin{array}{c}\text { AD + } \\
\text { converters } \\
(\mathbf{N}=129)\end{array}$ \\
\hline Female & $76(50.3 \%)$ & $68(42.2 \%)$ & $51(45.1 \%)$ & $16(45.7 \%)$ & $59(52.2 \%)$ & $58(45 \%)$ \\
\hline $\begin{array}{c}\text { Mean age } \\
\text { (years) }\end{array}$ & $74(5.5)$ & $70.1(6.8)$ & $71.7(7.1)$ & $74.7(8.1)$ & $73.7(5.6)$ & $73.2(7.1)$ \\
\hline $\begin{array}{c}\text { Mean } \\
\text { education } \\
\text { (years) }\end{array}$ & $16.5(2.7)$ & $16.3(2.7)$ & $16.2(2.9)$ & $15.2(2.6)$ & $16.8(2.5)$ & $15.8(2.7)$ \\
\hline
\end{tabular}

Data are number (\%) or mean (std). 
medRxiv preprint doi: https://doi.org/10.1101/2021.02.23.21252283; this version posted March 1, 2021. The copyright holder for this preprint (which was not certified by peer review) is the author/funder, who has granted medRxiv a license to display the preprint in perpetuity.

Supplementary File 2: List of 976 genes used in this study.

\section{Genes}

AARS, ABCB6, ABCC5, ABCF1, ABCF3, ABHD4, ABHD6, ABL1, ACAA1, ACAT2, ACBD3, ACD, ACLY, ACOT9, ADAM10, ADAT1, ADGRE5, ADGRG1, ADH5, ADI1, ADO, ADRB2, AGL, AKAP8, AKAP8L, AKR7A2, AKT1, ALAS1, ALDH7A1, ALDOA, ALDOC, AMDHD2, ANKRD10, ANO10, ANXA7, APBB2, APOE, APP, APPBP2, ARFIP2, ARHGAP1, ARHGEF12, ARHGEF2, ARID4B, ARID5B, ARL4C, ARNT2, ARPP19, ASAH1, ASCC3, ATF1, ATF5, ATF6, ATG3, ATMIN, ATP11B, ATP1B1, ATP2C1, ATP5S, ATP6V0B, ATP6V1D, AURKA, AURKB, AXIN1, B4GAT1, BACE2, BAD, BAG3, BAMBI, BAX, BCL2, BCL7B, BDH1, BECN1, BHLHE40, BID, BIRC2, BIRC5, BLCAP, BLMH, BLVRA, BMP4, BNIP3, BNIP3L, BPHL, BRCA1, BTK, BUB1B, BZW2, C2CD2, C2CD2L, C2CD5, C5, CAB39, CALM3, CALU, CAMSAP2, CANT1, CAPN1, CARMIL1, CASC3, CASK, CASP10, CASP2, CASP3, CASP7, CAST, CAT, CBLB, CBR1, CBR3, CCDC85B, CCDC86, CCDC92, CCL2, CCNA1, CCNA2, CCNB1, CCNB2, CCND1, CCND3, CCNE2, CCNF, CCNH, CCP110, CD320, CD40, CD44, CD58, CDC20, CDC25A, CDC25B, CDC42, CDC45, CDCA4, CDH3, CDK1, CDK19, CDK2, CDK4, CDK5R1, CDK6, CDK7, CDKN1A, CDKN1B, CDKN2A, CEBPA, CEBPD, CEBPZ, CENPE, CEP57, CERK, CETN3, CFLAR, CGRRF1, CHAC1, CHEK1, CHEK2, CHERP, CHIC2, CHMP4A, CHMP6, CHN1, CHP1, CIAPIN1, CIRBP, CISD1, CLIC4, CLPX, CLSTN1, CLTB, CLTC, CNDP2, CNOT4, CNPY3, COASY, COG2, COG4, COG7, COL1A1, COL4A1, COPB2, COPS7A, COQ8A, CORO1A, CPNE3, CPSF4, CREB1, CREG1, CRELD2, CRK, CRKL, CRTAP, CRYZ, CSK, CSNK1A1, CSNK1E, CSNK2A2, CSRP1, CTNNAL1, CTNND1, CTSD, CTSL, CTTN, CXCL2, CXCR4, CYB561, CYCS, CYTH1, DAG1, DAXX, DCK, DCTD, DCUN1D4, DDB2, DDIT4, DDR1, DDX10, DDX42, DECR1, DENND2D, DERA, DFFA, DFFB, DHDDS, DHRS7, DHX29, DLD, DMTF1, DNAJA3, DNAJB1, DNAJB2, DNAJB6, DNAJC15, DNM1, DNM1L, DNMT1, DNMT3A, DNTTIP2, DPH2, DRAP1, DSG2, DUSP11, DUSP14, DUSP22, DUSP3, DUSP4, DUSP6, DYNLT3, DYRK3, E2F2, EAPP, EBNA1BP2, EBP, ECD, ECH1, EDEM1, EDN1, EED, EFCAB14, EGF, EGFR, EGR1, EIF4EBP1, EIF4G1, EIF5, ELAC2, ELAVL1, ELOVL6, EML3, ENOPH1, ENOSF1, EPB41L2, EPHA3, EPHB2, EPN2, EPRS, ERBB2, ERBB3, ERO1A, ETFB, ETS1, ETV1, EVL, EXOSC4, EXT1, EZH2, FAH, FAIM, FAM20B, FAM57A, FAM69A, FAS, FASTKD5, FAT1, FBXL12, FBX011, FBXO21, FBXO7, FCHO1, FDFT1, FEZ2, FGFR2, FGFR4, FHL2, FIS1, FKBP14, FKBP4, FOS, FOSL1, FOXJ3, FOXO3, FOXO4, FPGS, FRS2, FSD1, FUT1, FYN, FZD1, FZD7, G3BP1, GAA, GABPB1, GADD45A, GADD45B, GALE, GAPDH, GATA2, GATA3, GDPD5, GFOD1, GFPT1, GHR, GLI2, GLOD4, GLRX, GMNN, GNA11, GNA15, GNAI1, GNAI2, GNAS, GNB5, GNPDA1, GOLT1B, GPATCH8, GPC1, GPER1, GRB10, GRB7, GRN, GRWD1, GSTM2, GSTZ1, GTF2A2, GTF2E2, GTPBP8, H2AFV, HACD3, HADH, HAT1, HDAC2, HDAC6, HDGFRP3, HEATR1, HEBP1, HERC6, HERPUD1, HES1, HIF1A, HIST1H2BK, HIST2H2BE, HK1, HLA-DMA, HLA-DRA, HMG20B, HMGA2, HMGCR, HMGCS1, HMOX1, HN1L, HOMER2, HOOK2, HOXA10, HOXA5, HPRT1, HS2ST1, HSD17B10, HSD17B11, HSPA1A, HSPA4, HSPA8, HSPB1, HSPD1, HTATSF1, HTRA1, HYOU1, IARS2, ICAM1, ICAM3, ICMT, ID2, IDE, IER3, IFNAR1, IFRD2, IGF1R, IGF2BP2, IGF2R, IGFBP3, IGHMBP2, IKBKAP, IKBKB, IKBKE, IKZF1, IL13RA1, IL1B, IL4R, ILK, INPP1, INPP4B, 
medRxiv preprint doi: https://doi.org/10.1101/2021.02.23.21252283; this version posted March 1, 2021. The copyright holder for this preprint (which was not certified by peer review) is the author/funder, who has granted medRxiv a license to display the preprint in perpetuity.

INSIG1, INTS3, IPO13, IQGAP1, ISOC1, ITFG1, ITGAE, ITGB1BP1, ITGB5, JADE2, JMJD6, JUN, KAT6A, KAT6B, KCNK1, KCTD5, KDELR2, KDM3A, KDM5A, KDM5B, KEAP1, KIAA0100, KIAA0355, KIAA0753, KIAA0907, KIF14, KIF1BP, KIF20A, KIF2C, KIF5C, KIT, KLHDC2, KLHL21, KLHL9, KTN1, LAGE3, LAMA3, LAP3, LBR, LGALS8, LGMN, LIG1, LIPA, LOXL1, LPAR2, LPGAT1, LRP10, LRPAP1, LRRC41, LSM5, LSM6, LSR, LYN, LYPLA1, LYRM1, MACF1, MALT1, MAMLD1, MAN2B1, MAP2K5, MAP3K4, MAP4K4, MAP7, MAPK13, MAPK1IP1L, MAPK9, MAPKAPK2, MAPKAPK3, MAPKAPK5, MAST2, MAT2A, MBNL1, MBNL2, MBOAT7, MBTPS1, MCM3, MCOLN1, MCUR1, ME2, MEF2C, MELK, MEST, METRN, MFSD10, MICALL1, MIF, MINDY1, MKNK1, MLEC, MLLT11, MMP1, MMP2, MNAT1, MOK, MPC2, MPZL1, MRPL12, MRPL19, MRPS16, MRPS2, MSH6, MSRA, MTA1, MTERF3, MTF2, MTFR1, MTHFD2, MUC1, MVP, MYBL2, MYC, MYCBP, MYCBP2, MYL9, MYLK, MYO10, NARFL, NCAPD2, NCK1, NCK2, NCOA3, NENF, NET1, NFATC3, NFATC4, NFE2L2, NFIL3, NFKB2, NFKBIA, NFKBIB, NFKBIE, NGRN, NIPSNAP1, NISCH, NIT1, NMT1, NNT, NOL3, NOLC1, NOS3, NOSIP, NOTCH1, NPC1, NPDC1, NPEPL1, NPRL2, NR1H2, NR2F6, NR3C1, NRAS, NRIP1, NSDHL, NT5DC2, NUCB2, NUDCD3, NUDT9, NUP133, NUP62, NUP85, NUP88, NUP93, NUSAP1, NVL, ORC1, OXA1L, OXCT1, OXSR1, P4HA2, P4HTM, PACSIN3, PAF1, PAFAH1B1, PAFAH1B3, PAICS, PAK1, PAK4, PAK6, PAN2, PAPD7, PARP1, PARP2, PAX8, PCBD1, PCCB, PCK2, PCM1, PCMT1, PCNA, PDGFA, PDHX, PDIA5, PDLIM1, PDS5A, PECR, PEX11A, PFKL, PGAM1, PGM1, PGRMC1, PHGDH, PHKA1, PHKB, PHKG2, PIGB, PIH1D1, PIK3C2B, PIK3C3, PIK3CA, PIK3R3, PIK3R4, PIN1, PIP4K2B, PKIG, PLA2G15, PLA2G4A, PLCB3, PLEKHJ1, PLEKHM1, PLK1, PLOD3, PLP2, PLS1, PLSCR1, PLSCR3, PMAIP1, PMM2, PNKP, PNP, POLB, POLD4, POLE2, POLG2, POLR1C, POLR2I, POLR2K, POP4, PPARD, PPARG, PPIC, PPIE, PPOX, PPP1R13B, PPP2R3C, PPP2R5A, PPP2R5E, PRAF2, PRCP, PRKACA, PRKAG2, PRKCD, PRKCH, PRKCQ, PRKX, PROS1, PRPF4, PRR15L, PRR7, PRSS23, PRUNE1, PSIP1, PSMB10, PSMB8, PSMD10, PSMD2, PSMD4, PSMD9, PSME1, PSME2, PSMF1, PSMG1, PSRC1, PTGS2, PTK2, PTK2B, PTPN1, PTPN12, PTPN6, PTPRC, PTPRF, PTPRK, PUF60, PWP1, PXN, PYCR1, PYGL, RAB11FIP2, RAB21, RAB27A, RAB31, RAB4A, RAC2, RAD51C, RAD9A, RAE1, RAI14, RALA, RALB, RALGDS, RAP1GAP, RASA1, RB1, RBKS, RBM15B, RBM34, RBM6, REEP5, RELB, RFC2, RFC5, RFNG, RFX5, RGS2, RHEB, RHOA, RNF167, RNH1, RNMT, RNPS1, RPA1, RPA2, RPA3, RPIA, RPL39L, RPN1, RPP38, RPS5, RPS6, RPS6KA1, RRAGA, RRP12, RRP1B, RRP8, RRS1, RSU1, RTN2, RUVBL1, S100A13, S100A4, SACM1L, SATB1, SCAND1, SCARB1, SCCPDH, SCP2, SCRN1, SCYL3, SDHB, SENP6, SERPINE1, SESN1, SFN, SGCB, SH3BP5, SHB, SHC1, SIRT3, SKIV2L, SKP1, SLC11A2, SLC1A4, SLC25A13, SLC25A14, SLC25A4, SLC25A46, SLC27A3, SLC2A6, SLC35A1, SLC35A3, SLC35B1, SLC35F2, SLC37A4, SLC5A6, SMAD3, SMARCA4, SMARCC1, SMARCD2, SMC1A, SMC3, SMC4, SMNDC1, SNAP25, SNCA, SNX11, SNX13, SNX6, SNX7, SOCS2, SORBS3, SOX2, SOX4, SPAG4, SPAG7, SPDEF, SPEN, SPP1, SPR, SPRED2, SPTAN1, SPTLC2, SQRDL, SQSTM1, SRC, SSBP2, ST3GAL5, ST6GALNAC2, ST7, STAMBP, STAP2, STAT1, STAT3, STAT5B, STK10, STK25, STMN1, STUB1, STX1A, STX4, STXBP1, STXBP2, SUPV3L1, SUV39H1, SUZ12, SYK, SYNE2, SYNGR3, SYPL1, TARBP1, TATDN2, TBC1D31, TBC1D9B, TBP, TBPL1, TBX2, TBXA2R, TCEA2, TCEAL4, 
medRxiv preprint doi: https://doi.org/10.1101/2021.02.23.21252283; this version posted March 1, 2021. The copyright holder for this preprint (which was not certified by peer review) is the author/funder, who has granted medRxiv a license to display the preprint in perpetuity.

It is made available under a CC-BY-NC-ND 4.0 International license .

TCERG1, TCFL5, TCTA, TCTN1, TERF2IP, TERT, TES, TESK1, TEX10, TFAP2A, TFDP1, TGFB3, TGFBR2, THAP11, TIAM1, TICAM1, TIMELESS, TIMM17B, TIMM22, TIMM9, TIMP2, TIPARP, TJP1, TLE1, TLK2, TLR4, TM9SF2, TM9SF3, TMCO1, TMED10, TMEM109, TMEM110, TMEM2, TMEM5, TMEM50A, TMEM97, TNFRSF21, TNIP1, TOMM34, TOMM70, TOP2A, TOPBP1, TOR1A, TP53, TP53BP1, TP53BP2, TPD52L2, TPM1, TRAK2, TRAM2, TRAP1, TRAPPC3, TRAPPC6A, TRIB1, TRIB3, TRIM13, TRIM2, TSC22D3, TSEN2, TSKU, TSPAN3, TSPAN4, TSPAN6, TSTA3, TWF2, TXLNA, TXNDC9, TXNL4B, TXNRD1, UBE2A, UBE2C, UBE2J1, UBE2L6, UBE3B, UBE3C, UBQLN2, UBR7, UFM1, UGDH, USP1, USP14, USP22, USP6NL, USP7, UTP14A, VAPB, VAT1, VAV3, VDAC1, VGLL4, VPS28, VPS72, WASF3, WASHC4, WASHC5, WDR61, WDR7, WDTC1, WFS1, WIPF2, WRB, XBP1, XPNPEP1, XPO7, YKT6, YME1L1, YTHDF1, ZDHHC6, ZFP36, ZMIZ1, ZMYM2, ZNF131, ZNF274, ZNF318, ZNF395, ZNF451, ZNF586, ZNF589, ZW10.

Supplementary File 3: Brain regions used in this study. A total of 144 regions (72 regions each in both hemispheres) were derived from Julich and Brodmann's atlases.

\begin{tabular}{|c|c|c|c|}
\hline Number & Julich Atlas & Number & Brodmann's Atlas \\
\hline 1 & hOc1 & 44 & Brodmann's area 1 \\
\hline 2 & hOc2 & 45 & Brodmann's area 2 \\
\hline 3 & hOc4d & 46 & Brodmann's area 3 \\
\hline 4 & hOc3d & 47 & Brodmann's area 4 \\
\hline 5 & hOc3v & 48 & Brodmann's area 5 \\
\hline 6 & hOc4v & 49 & Brodmann's area 6 \\
\hline 7 & 1 & 50 & Brodmann's area 7 \\
\hline 8 & 2 & 51 & Brodmann's area 10 \\
\hline 9 & †3a & 52 & Brodmann's area 11 \\
\hline 10 & $3 b$ & 53 & Brodmann's area 17 \\
\hline 11 & FG1 & 54 & †*Brodmann's area 18 \\
\hline 12 & FG2 & 55 & Brodmann's area 19 \\
\hline 13 & Brodmann's area 37 & 56 & Brodmann's area 24 \\
\hline 14 & Te1 & 57 & Brodmann's area 25 \\
\hline 15 & Te2 & 58 & Brodmann's area 26 \\
\hline 16 & Brodmann's area 20 & 59 & Brodmann's area 27 \\
\hline 17 & Brodmann's area 21 & 60 & Brodmann's area 29 \\
\hline 18 & Brodmann's area 22 & 61 & $\dagger^{*}$ Brodmann's area 30 \\
\hline 19 & Brodmann's area 36 & 62 & Brodmann's area 32 \\
\hline 20 & Brodmann's area 38 & 63 & Brodmann's area 34 \\
\hline 21 & $5 \mathrm{~L}$ & 64 & Brodmann's area 35 \\
\hline 22 & $5 \mathrm{M}$ & 65 & Brodmann's area 39 \\
\hline
\end{tabular}




\begin{tabular}{|c|c|c|c|}
\hline Number & Julich Atlas & Number & Brodmann's Atlas \\
\hline 23 & $\overline{P G a}$ & $\overline{66}$ & Brodmann's area 40 \\
\hline 24 & PGp & 67 & †Brodmann's area 41 \\
\hline 25 & PFt & 68 & Brodmann's area 42 \\
\hline 26 & PFm & 69 & Brodmann's area 43 \\
\hline 27 & p24ab & 70 & Brodmann's area 44 \\
\hline 28 & p32 & 71 & Brodmann's area 45 \\
\hline 29 & Brodmann's area 23 & 72 & Brodmann's area 48 \\
\hline 30 & 6 & & \\
\hline 31 & $4 p$ & & \\
\hline 32 & Brodmann's area 8 & & \\
\hline 33 & Brodmann's area 9 & & \\
\hline 34 & Fp1 & & \\
\hline 35 & Fp2 & & \\
\hline 36 & Fo1 & & \\
\hline 37 & 44 & & \\
\hline 38 & 45 & & \\
\hline 39 & Brodmann's area 46 & & \\
\hline 40 & Brodmann's area 47 & & \\
\hline 41 & $7 A$ & & \\
\hline 42 & CA+dentate & & \\
\hline 43 & Brodmann's area 28 & & \\
\hline
\end{tabular}

* Region excluded from the left hemisphere $\dagger$ Region excluded from the right hemisphere

Supplementary File 4: Distribution of stable gene-imaging interaction parameters in healthy aging and $A D$ progression $(99 \% \mathrm{Cl})$.

\begin{tabular}{|c|c|c|c|c|c|c|c|c|c|c|c|c|c|}
\hline & & \multicolumn{12}{|c|}{ Longitudinal biological factor alterations } \\
\hline & & \multicolumn{2}{|c|}{$\mathrm{CBF}$} & \multicolumn{2}{|c|}{$A \beta$} & \multicolumn{2}{|c|}{ Functional activity } & \multicolumn{2}{|c|}{ Glucose metabolism } & \multicolumn{2}{|c|}{ Grey matter density } & \multicolumn{2}{|c|}{ Tau } \\
\hline & & Healthy & $\mathrm{AD}$ & Healthy & $A D$ & Healthy & AD & Healthy & $A D$ & Healthy & AD & Healthy & $A D$ \\
\hline \multirow{6}{*}{ 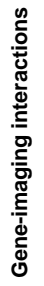 } & CBF & 0 & 17 & 5 & 34 & 3 & 28 & 2 & 19 & 0 & 13 & 3 & 31 \\
\hline & $A \beta$ & 0 & 74 & 4 & 40 & 4 & 20 & 0 & 19 & 1 & 15 & 2 & 17 \\
\hline & Functional activity & 1 & 41 & 2 & 14 & 0 & 17 & 0 & 15 & 1 & 11 & 2 & 30 \\
\hline & Glucose metabolism & 2 & 78 & 3 & 35 & 1 & 24 & 1 & 33 & 1 & 10 & 2 & 28 \\
\hline & Grey matter density & 1 & 53 & 2 & 37 & 5 & 36 & 2 & 30 & 1 & 21 & 1 & 39 \\
\hline & Tau & 1 & 10 & 4 & 17 & 3 & 15 & 0 & 9 & 0 & 10 & 8 & 53 \\
\hline & Total & 5 & 273 & 20 & 177 & 16 & 140 & 5 & 125 & 4 & 80 & 18 & 198 \\
\hline
\end{tabular}


medRxiv preprint doi: https://doi.org/10.1101/2021.02.23.21252283; this version posted March 1, 2021. The copyright holder for this preprint (which was not certified by peer review) is the author/funder, who has granted medRxiv a license to display the preprint in perpetuity.

Supplementary File 5: Identified molecular pathways underlying AD progression.

\begin{tabular}{|c|c|}
\hline Pathway & No of genes \\
\hline CCKR signaling map & 8 \\
\hline $\begin{array}{l}\text { Inflammation mediated by chemokine and cytokine signaling } \\
\text { pathway }\end{array}$ & 6 \\
\hline Apoptosis signaling pathway & 5 \\
\hline Gonadotropin-releasing hormone receptor pathway & 5 \\
\hline $\begin{array}{l}\text { Heterotrimeric G-protein signaling pathway-Gi alpha and Gs } \\
\text { alpha mediated pathway }\end{array}$ & 3 \\
\hline FAS signaling pathway & 3 \\
\hline p38 MAPK pathway & 3 \\
\hline Enkephalin release & 3 \\
\hline Beta3 adrenergic receptor signaling pathway & 2 \\
\hline Beta2 adrenergic receptor signaling pathway & 2 \\
\hline Beta1 adrenergic receptor signaling pathway & 2 \\
\hline 5HT4 type receptor mediated signaling pathway & 2 \\
\hline Angiogenesis & 2 \\
\hline Alzheimer disease-presenilin pathway & 2 \\
\hline Ubiquitin proteasome pathway & 2 \\
\hline Wnt signaling pathway & 2 \\
\hline $\mathrm{N}$-acetylglucosamine metabolism & 2 \\
\hline Cytoskeletal regulation by Rho GTPase & 2 \\
\hline Histamine $\mathrm{H} 2$ receptor mediated signaling pathway & 2 \\
\hline Cell cycle & 2 \\
\hline B cell activation & 2 \\
\hline Cortocotropin releasing factor receptor signaling pathway & 2 \\
\hline Axon guidance mediated by netrin & 1 \\
\hline Axon guidance mediated by Slit/Robo & 1 \\
\hline Metabotropic glutamate receptor group III pathway & 1 \\
\hline JAK/STAT signaling pathway & 1 \\
\hline Interleukin signaling pathway & 1 \\
\hline Interferon-gamma signaling pathway & 1 \\
\hline 5HT2 type receptor mediated signaling pathway & 1 \\
\hline Coenzyme A biosynthesis & 1 \\
\hline 5HT1 type receptor mediated signaling pathway & 1 \\
\hline Insulin/IGF pathway-protein kinase B signaling cascade & 1 \\
\hline $\begin{array}{l}\text { Insulin/IGF pathway-mitogen activated protein kinase kinase/MAP } \\
\text { kinase cascade }\end{array}$ & 1 \\
\hline Huntington disease & 1 \\
\hline $\begin{array}{l}\text { Heterotrimeric G-protein signaling pathway-rod outer segment } \\
\text { phototransduction }\end{array}$ & 1 \\
\hline p53 pathway & 1 \\
\hline p53 pathway feedback loops 2 & 1 \\
\hline $\begin{array}{l}\text { Heterotrimeric G-protein signaling pathway-Gq alpha and Go } \\
\text { alpha mediated pathway }\end{array}$ & 1 \\
\hline p53 pathway by glucose deprivation & 1 \\
\hline O-antigen biosynthesis & 1 \\
\hline
\end{tabular}


medRxiv preprint doi: https://doi.org/10.1101/2021.02.23.21252283; this version posted March 1, 2021. The copyright holder for this preprint (which was not certified by peer review) is the author/funder, who has granted medRxiv a license to display the preprint in perpetuity.

It is made available under a CC-BY-NC-ND 4.0 International license.

\begin{tabular}{|l|l|}
\hline Xanthine and guanine salvage pathway & 1 \\
\hline Transcription regulation by bZIP transcription factor & 1 \\
\hline Thyrotropin-releasing hormone receptor signaling pathway & 1 \\
\hline Toll receptor signaling pathway & 1 \\
\hline Ras Pathway & 1 \\
\hline Adenine and hypoxanthine salvage pathway & 1 \\
\hline T cell activation & 1 \\
\hline Oxytocin receptor mediated signaling pathway & 1 \\
\hline Endothelin signaling pathway & 1 \\
\hline EGF receptor signaling pathway & 1 \\
\hline Parkinson disease & 1 \\
\hline DNA replication & 1 \\
\hline PI3 kinase pathway & 1 \\
\hline Opioid proopiomelanocortin pathway & 1 \\
\hline PDGF signaling pathway & 1 \\
\hline Opioid prodynorphin pathway & 1 \\
\hline Oxidative stress response & 1 \\
\hline Opioid proenkephalin pathway & 1 \\
\hline Cholesterol biosynthesis & 1 \\
\hline
\end{tabular}

